\title{
A comprehensive biogeochemical record and annual flux estimates for the Sabaki River (Kenya)
}

\author{
Trent R. Marwick ${ }^{1}$, Fredrick Tamooh ${ }^{2}$, Bernard Ogwoka $^{3}$, Alberto V. Borges ${ }^{4}$, François Darchambeau ${ }^{4}$, and \\ Steven Bouillon ${ }^{1}$ \\ ${ }^{1}$ Department of Earth and Environmental Sciences, KU Leuven, Leuven, 3001, Belgium \\ ${ }^{2}$ Kenyatta University, Department of Zoological Sciences, Mombasa, Kenya \\ ${ }^{3}$ Kenya Wildlife Service, Mombasa, Kenya \\ ${ }^{4}$ Unité d'Océanographie Chimique, Université de Liège, Liège, 4000, Belgium
}

Correspondence: Trent R. Marwick (trent.marwick@gmail.com)

Received: 13 July 2017 - Discussion started: 9 August 2017

Revised: 28 January 2018 - Accepted: 15 February 2018 - Published: 21 March 2018

\begin{abstract}
Inland waters impart considerable influence on nutrient cycling and budget estimates across local, regional and global scales, whilst anthropogenic pressures, such as rising populations and the appropriation of land and water resources, are undoubtedly modulating the flux of carbon (C), nitrogen $(\mathrm{N})$ and phosphorus $(\mathrm{P})$ between terrestrial biomes to inland waters, and the subsequent flux of these nutrients to the marine and atmospheric domains. Here, we present a 2-year biogeochemical record (October 2011-December 2013) at biweekly sampling resolution for the lower Sabaki River, Kenya, and provide estimates for suspended sediment and nutrient export fluxes from the lower Sabaki River under pre-dam conditions, and in light of the approved construction of the Thwake Multipurpose Dam on its upper reaches (Athi River). Erratic seasonal variation was typical for most parameters, with generally poor correlation between discharge and material concentrations, and stable isotope values of $\mathrm{C}\left(\delta^{13} \mathrm{C}\right)$ and $\mathrm{N}\left(\delta^{15} \mathrm{~N}\right)$. Although high total suspended matter (TSM) concentrations are reported here (up to $\sim 3.8 \mathrm{~g} \mathrm{~L}^{-1}$ ), peak concentrations of TSM rarely coincided with peak discharge. The contribution of particulate organic C (POC) to the TSM pool indicates a wide biannual variation in suspended sediment load from OC poor $(0.3 \%)$ to OC rich $(14.9 \%)$, with the highest \% POC occurring when discharge is $<100 \mathrm{~m}^{3} \mathrm{~s}^{-1}$ and at lower TSM concentrations. The consistent ${ }^{15} \mathrm{~N}$ enrichment of the particulate nitrogen (PN) pool compared to other river systems indicates anthropogenic $\mathrm{N}$ loading is a year-round driver of $\mathrm{N}$ export from the Sabaki Basin. The lower Sabaki River was consis-
\end{abstract}

tently oversaturated in dissolved methane $\left(\mathrm{CH}_{4}\right.$; from 499 to $135111 \%)$ and nitrous oxide $\left(\mathrm{N}_{2} \mathrm{O} ; 100\right.$ to $\left.463 \%\right)$ relative to atmospheric concentrations. Wet season flows (OctoberDecember and March-May) carried $>80 \%$ of the total load for TSM $(\sim 86 \%)$, POC $(\sim 89 \%)$, dissolved organic carbon (DOC; $\sim 81 \%)$, PN $(\sim 89 \%)$ and particulate phosphorus (TPP; $\sim 82 \%$ ), with $>50 \%$ of each fraction exported during the long wet season (March-May). Our estimated sediment yield $\left(85 \mathrm{Mg} \mathrm{km}^{-2} \mathrm{yr}^{-1}\right)$ is relatively low on the global scale and is considerably less than the recently reported average sediment yield of $\sim 630 \mathrm{Mg} \mathrm{km}^{-2} \mathrm{yr}^{-1}$ for African river basins. Regardless, sediment and $\mathrm{OC}$ yields were all at least equivalent or greater than reported yields for the neighbouring dammed Tana River. Rapid pulses of heavily ${ }^{13} \mathrm{C}$ enriched POC coincided with peak concentrations of PN, ammonium, $\mathrm{CH}_{4}$ and low dissolved oxygen saturation, suggesting that large mammalian herbivores (e.g. hippopotami) may mediate the delivery of $\mathrm{C}_{4}$ organic matter to the river during the dry season. Given recent projections for increasing dissolved nutrient export from African rivers, as well as the planned damming of the Athi River, these first estimates of material fluxes from the Sabaki River provide base-line data for future research initiatives assessing anthropogenic perturbation of the Sabaki Basin. 


\section{Introduction}

The acknowledgement of the vital role inland waters play in carbon (C) cycling and budget estimates at local, regional and global scales has progressed steadily over the past three decades (e.g. Meybeck, 1982; Cole et al., 2007; Tranvik et al., 2009). For example, inland waters not only act as a conduit for the delivery of significant quantities of terrestrial organic $\mathrm{C}$ to the coastal zone and open ocean, they are typically sources of greenhouse gases (GHGs: e.g. $\mathrm{CO}_{2}, \mathrm{CH}_{4}$, $\mathrm{N}_{2} \mathrm{O}$ ) to the atmosphere. These GHGs can be derived either from instream remineralisation of a proportion of lateral inputs, through inputs from groundwater and floodwater carrying the products of terrestrial mineralisation (Cole and Caraco, 2001a; Beaulieu et al., 2011; Raymond et al., 2013) or from wetlands (Abril et al., 2014; Borges et al., 2015a). Recent data compilations further elucidate the controls and drivers of GHG dynamics within the fluvial domain at regional and global scales (Borges et al., 2015a; Stanley et al., 2016; Marzadri et al., 2017). Additionally, a quantity of the lateral inputs may be buried within sedimentary deposits of reservoirs, lakes, floodplains and wetlands (Cole et al., 2007; Battin et al., 2008; Aufdenkampe et al., 2011). Anthropogenic pressures, such as land-use and land-use change, are undoubtedly modulating the quantities involved in each of these exchange fluxes (Regnier et al., 2013).

Given that recent reports assert a similar order of magnitude to the lateral $\mathrm{C}$ input to inland waters $(\sim 2.3$ up to 5.1 $\mathrm{Pg} \mathrm{C} \mathrm{yr}^{-1}$; Cole et al., 2007; Battin et al., 2009; Drake et al., 2018) as that for global net ecosystem production ( $\sim 2 \mathrm{Pg} \mathrm{Cyr}^{-1}$; Ciais et al., 2013), the scarcity of the biogeochemistry database for some regional inland waters is key to our inability to adequately resolve the role of this biosphere domain within broader regional and global $\mathrm{C}$ budgets (Regnier et al., 2013; Raymond et al., 2013). Although the spotlight has turned somewhat towards establishing a comprehensive reckoning of riverine $\mathrm{C}$ source variability and constraining $\mathrm{C}$ cycling within river basins, rather than solely quantifying the transport fluxes from inland waters to the coastal zone (Bouillon et al., 2012), there remain important inland water systems or regions lacking long-term, riverine biogeochemical datasets built upon high-frequency sampling initiatives capable of providing reliable transport flux estimates. Tropical and sub-tropical Africa is one region where such datasets are scarce (e.g. Coynel et al., 2005; Borges et al., 2015a), and they thus contribute some of the largest uncertainty to global C budgets (Ciais et al., 2011). On the global scale, the tropics and subtropics are considered of particular importance regarding the transport of sediments and C (Ludwig et al., 1996; Schlünz and Schneider, 2000; Moore et al., 2011), with a recent compilation of African sediment yield (hereafter SY) data highlighting the paucity of observations relative to other continental regions (Vanmaercke et al., 2014). Also, the inland waters of the tropics and subtropics are suggested to have elevated evasion rates of $\mathrm{CO}_{2}$ to the atmosphere in comparison to temperate and boreal inland waters (Aufdenkampe et al., 2011; Raymond et al., 2013; Borges et al., 2015a, b), and the same has been asserted for global $\mathrm{CH}_{4}$ flux from tropical rivers and lakes (Bastviken et al., 2011; Borges et al., 2015a, b). Hence, given their reported significance as a source of GHGs to the atmosphere, an increased focus on the inland water biogeochemistry of the tropics is merited (Regnier et al., 2013; Stanley et al., 2016), particularly for data-scarce river basins of Africa.

Over the past decade, momentum has gathered towards a broader understanding of the nutrient cycling within subSaharan inland water ecosystems (e.g. Coynel et al., 2005; Abrantes et al., 2013; Bouillon et al., 2014). However, Africa has experienced the highest annual population growth rate over the past 60 years $(\sim 2.51 \%, 1950-2013$; see United Nations, 2013), a position it is expected to hold for the remainder of the 21st century (United Nations, 2013). Coupling the increasing population with forecasted climate change scenarios, land-use changes including deforestation and the expansion of agriculture, reservoir construction and water abstraction and the increased exploitation of natural resources will shift the dynamics of lateral nutrient inputs to inland waters of Africa, the balance between transport and in situ processing of these terrestrial subsidies and consequently the regional C and nutrient balance of Africa (Yasin et al., 2010; Ciais et al., 2011; Valentini et al., 2014). Hence, continued effort in characterising the biogeochemistry of African inland waters is paramount for developing robust regional and global nutrient budgets, but also to provide a working baseline for assessing future climate and land-use impacts on the nutrient fluxes to and from inland waters of Africa.

The potential perturbation of the biogeochemistry of tropical inland waters by climate and land-use change (Hamilton, 2010), and that of Africa specifically (Yasin et al., 2010), has received some attention. Given a projected warming of a $\sim 2-4.5^{\circ} \mathrm{C}$ toward the end of the 21 st century within the tropics (Meehl et al., 2007; Buontempo et al., 2015) and in East Africa specifically (Buontempo et al., 2015; Dosio and Panitz, 2016), important shifts are predicted involving (i) aquatic thermal regime, influencing rates of in situ microbe-mediated biogeochemical processes, (ii) hydrological regimes of discharge and floodplain inundation and (iii) freshwater-saltwater gradients, altering biogeochemical processing as rivers approach the coastal zone. Additionally, Yasin et al. (2010) estimate that the load of all dissolved and particulate forms of $\mathrm{C}, \mathrm{N}$ and $\mathrm{P}$ in African river basins increased in the period 1970-2000, and further increases are predicted for all dissolved fractions of $\mathrm{N}$ and $\mathrm{P}$ between 2000-2050, although C fractions and particulate forms of $\mathrm{N}$ and $\mathrm{P}$ are modelled to decrease. Predicted decreases of particulate loads are linked to the net effect of climate change and reservoir construction, which alter hydrology, nutrient retention and sediment carrying capacity of rivers (Yasin et al., 2010), and which store $\sim 25 \%$ of annual sediment load carried over the African landmass (Syvitski et al., 2005), while 
the increasing dissolved nutrient loads are related to the rising population and with increased per capita gross domestic product (GDP) and meat consumption, with these factors driving up the terrestrial inputs of manure-, fertiliser- and sewage-derived $\mathrm{N}$ and $\mathrm{P}$ (Yasin et al., 2010).

British settlement brought European land-use practices to the Kenyan highlands early in the 20th century, triggering severe soil erosion in, and elevated sediment fluxes from, the Athi-Galana-Sabaki (A-G-S) River basin (Champion, 1933; Fleitmann et al., 2007). These terrigenous sediments have had a significant impact on the environment surrounding the outflow of the Sabaki River in the Indian Ocean, for example, by increasing coral stress (van Katwijk et al., 1993) and spreading seagrass beds on local reef complexes, as well as siltation and infilling of the Sabaki estuary and the rapid progradation of nearby shorelines (Giesen and van de Kerkhof, 1984). In order to alleviate regional water scarcity, construction of reservoirs on the Athi River has been under consideration for decades, the implementation of which could modify the magnitude of sediment delivery to the coastal zone (van Katwijk et al., 1993) as previously observed in the neighbouring Tana River (Finn, 1983; Tamooh et al., 2012).

The lower Sabaki (also known as Galana) River forms after the confluence of the Athi and Tsavo rivers, and has been shown to be strongly influenced by nitrogen inputs from the greater Nairobi area (Marwick et al., 2014a), yet annual fluxes of particulate and dissolved elements have not been measured in detail. In light of the planned construction of the Thwake Multipurpose Dam (currently awaiting tender approval; see http://www.afdb.org/projects-and-operations/ project-portfolio/project/p-ke-e00-008/, last access: 15 January 2018), we here present a 2-year biogeochemical record at fortnightly resolution for the lower Sabaki River, and provide estimates for sediment and nutrient export rates from the A-G-S system whilst still under pre-dam conditions.

\section{Materials and methods}

\subsection{Study area}

The Athi-Galana-Sabaki River basin is the second largest drainage basin $\left(\sim 46600 \mathrm{~km}^{2}\right)$ in Kenya. The headwaters are located in central and south-east Kenya, in the vicinity of Nairobi (Fig. 1), draining agricultural areas (predominantly tea and coffee plantations) which provide the livelihood of $70 \%$ of the regional population (Kithiia, 1997). Industrial activities and informal settlements dominate land use around Nairobi, with livestock and small-scale irrigation activities also present downstream. The basin land cover is dominated by grasslands biomes $(\sim 65 \%)$ rich in $\mathrm{C}_{4}$ species (Fig. 1), with agriculture accounting for $\sim 15 \%$ and the region of Nairobi $<1 \%$. Forest biomes dominated by $\mathrm{C}_{3}$ vegetation are isolated to higher altitude regions in the basin headwaters, as well as in the coastal region where the Sabaki River discharges to the Indian Ocean at Malindi Bay (Fig. 1). The river is known as the Athi River in its upstream reaches, and after its confluence with the Tsavo River, becomes known as the Sabaki (or Galana) River (Fig. 1).

Precipitation ranges between 800 and $1200 \mathrm{~mm} \mathrm{yr}^{-1}$ in the highly populated central highlands surrounding Nairobi, and between 400 and $800 \mathrm{~mm} \mathrm{yr}^{-1}$ in less-populated, lower altitude, semi-arid south-east Kenya. Two dry seasons (JanuaryFebruary, hereafter JF; June-September, hereafter JJAS) intersperse a long (March-May, hereafter MAM) and short (October-December, hereafter OND) wet season. Only during the MAM and OND periods does monthly precipitation exceed potential evaporation-transpiration within the basin (Fig. 1), and accordingly the annual hydrograph displays bimodal discharge, with an average flow rate of $49 \mathrm{~m}^{3} \mathrm{~s}^{-1}$ between 1957-1979 (Fleitmann et al., 2007). Dry season flow rates as low as $0.5 \mathrm{~m}^{3} \mathrm{~s}^{-1}$ compare to peak wet season flow rates of up to $5000 \mathrm{~m}^{3} \mathrm{~s}^{-1}$ (Delft Hydraulics, 1970; Fleitmann et al., 2007). Oscillations between El Niño and La Niña conditions have a strong influence on the decadal patterns of river discharge, where extended severe drought is broken by intense and destructive flooding (Mogaka et al., 2006). The pre-1960 sediment flux of $0.06 \mathrm{Tg} \mathrm{yr}^{-1}$ is dwarfed by modern-day flux estimates of 5.7 and $14.3 \mathrm{Tg} \mathrm{yr}^{-1}$ (Van Katwijk et al., 1993; Kitheka, 2013), with the rapid increase in sediment flux over the past half-century attributed to a combination of intensified land use practices, the highly variable climatic conditions and extremely erosive native soils. More detailed information regarding basin settings may be found in Marwick et al. (2014a).

\subsection{Sampling and analytical techniques}

Physico-chemical parameters of the Sabaki River were monitored biweekly (i.e. fortnightly) approximately $2 \mathrm{~km}$ upstream of Sabaki Bridge (approximately $5 \mathrm{~km}$ upstream of the river outlet to Malindi Bay) for the period October 2011 to December 2013. This site was chosen since it is close to the outflow to the ocean and thus integrates the yields over the entire basin; however, it is not influenced by salinity intrusion or tidal influence. Water temperature, conductivity, dissolved oxygen $\left(\mathrm{O}_{2}\right)$ and $\mathrm{pH}$ were measured in situ with a YSI ProPlus multimeter, whereby the $\mathrm{O}_{2}$ and $\mathrm{pH}$ probes were calibrated on each day of data collection using water saturated air and United States National Bureau of Standards buffer solutions (4 and 7) respectively. Samples for dissolved gases $\left(\mathrm{CH}_{4}, \mathrm{~N}_{2} \mathrm{O}\right)$ and the stable isotope composition of dissolved inorganic $\mathrm{C}\left(\delta^{13} \mathrm{C}_{\mathrm{DIC}}\right)$ were collected from midstream at $\sim 0.5 \mathrm{~m}$ depth with a custom-made sampling bottle consisting of an inverted $1 \mathrm{~L}$ polycarbonate bottle with the bottom removed, and $\sim 0.5 \mathrm{~m}$ of tubing attached in the screw cap (Abril et al., 2007). Exetainer vials $(12 \mathrm{~mL})$ (for $\left.\delta^{13} \mathrm{C}_{\text {DIC }}\right)$ and $50 \mathrm{~mL}$ serum bottles (for $\mathrm{CH}_{4}$ and $\mathrm{N}_{2} \mathrm{O}$ ) were filled from water flowing from the outlet tubing, poisoned with $\mathrm{HgCl}_{2}$ and capped without headspace. Approximately $2000 \mathrm{~mL}$ of 

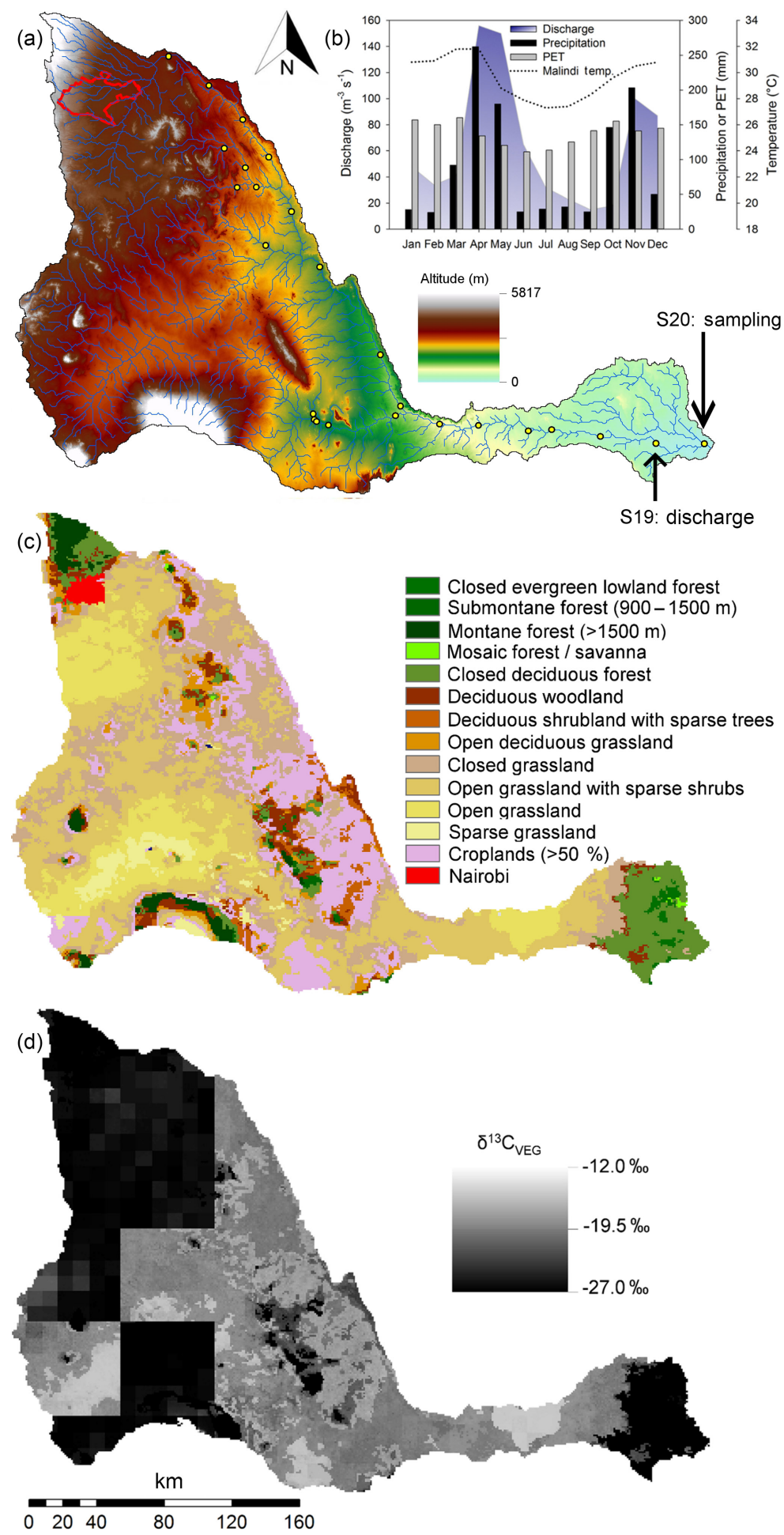

Figure 1. The Athi-Galana-Sabaki River basin: (a) digital elevation model; (b) mean monthly variation of hydrological and climate parameters including discharge at the outlet (shaded area; data from 1959-1977), precipitation (black bar; from Fleitmann et al., 2007), potential evapotranspiration (PET; grey box) and the maximum air temperature in Malindi (A-G-S outlet; dotted black line); (c) GLC2000 vegetation biomes (Mayaux et al., 2004); (d) crop-corrected vegetation "isoscape" (extracted from Still and Powell, 2010). The yellow dots in (a) mark the site locations from Marwick et al. (2014a), with the locations of biweekly sampling here (S20) and discharge data collection (S19) indicated, while the area of Nairobi is highlighted by the red outline in the upper basin. 
water was collected on each sampling occasion at $\sim 0.5 \mathrm{~m}$ below the water surface for other particulate and dissolved variables, with filtration and sample preservation performed in the field within $2 \mathrm{~h}$ of sampling.

Samples for total suspended matter (TSM) were obtained by filtering $60-250 \mathrm{~mL}$ of water using pre-combusted $(4 \mathrm{~h}$ at $\left.500{ }^{\circ} \mathrm{C}\right)$ and pre-weighed glass fibre filters $(47 \mathrm{~mm} \mathrm{GF} / \mathrm{F}$, $0.7 \mu \mathrm{m}$ nominal pore size) and then dried in ambient air during the fieldwork. Samples for determination of particulate organic $\mathrm{C}$ (POC), particulate nitrogen $(\mathrm{PN})$ and $\mathrm{C}$ isotope composition of POC $\left(\delta^{13} \mathrm{C}_{\mathrm{POC}}\right)$ were collected by filtering $40-60 \mathrm{~mL}$ of water on pre-combusted $\left(4 \mathrm{~h}\right.$ at $\left.500^{\circ} \mathrm{C}\right) 25 \mathrm{~mm}$ $\mathrm{GF} / \mathrm{F}$ filters $(0.7 \mu \mathrm{m}$ nominal pore size $)$. The filtrate from the TSM filtrations was further filtered with $0.2 \mu \mathrm{m}$ polyethersulfone syringe filters (Sartorius, 16532-Q) for total alkalinity (TA), DOC and $\delta^{13} \mathrm{C}_{\mathrm{DOC}}(8-40 \mathrm{~mL}$ glass vials with polytetrafluoroethylene coated septa). All samples were regularly shipped to the home laboratories for analyses, which typically took place within 6 months of sample collection.

TA was analysed by automated electro-titration on $50 \mathrm{~mL}$ samples with $0.1 \mathrm{~mol} \mathrm{~L}^{-1} \mathrm{HCl}$ as titrant (reproducibility estimated as typically better than $\pm 3 \mu \mathrm{mol} \mathrm{kg}{ }^{-1}$ based on replicate analyses). For the analysis of $\delta^{13} \mathrm{C}_{\text {DIC }}$, a $2 \mathrm{~mL}$ helium ( $\mathrm{He}$ ) headspace was created, and $\mathrm{H}_{3} \mathrm{PO}_{4}$ was added to convert all DIC species to $\mathrm{CO}_{2}$. After overnight equilibration, part of the headspace was injected into the He stream of an elemental analyser - isotope ratio mass spectrometer (EA-IRMS, Thermo Finnigan Flash HT and Thermo Finnigan DeltaV Advantage) for $\delta^{13} \mathrm{C}$ measurements. The obtained $\delta^{13} \mathrm{C}$ data were corrected for the isotopic equilibration between gaseous and dissolved $\mathrm{CO}_{2}$ as described in Gillikin and Bouillon (2007), and measurements were calibrated with certified reference materials LSVEC and either NBS-19 or IAEA-CO-1. Concentrations of $\mathrm{CH}_{4}$ and $\mathrm{N}_{2} \mathrm{O}$ were determined via the headspace equilibration technique (20 $\mathrm{mL} \mathrm{N}_{2}$ headspace in $50 \mathrm{~mL}$ serum bottles) and measured by gas chromatography (GC, Weiss, 1981) with flame ionisation detection (GC-FID) and electron capture detection (GC-ECD) with a SRI 8610C GC-FID-ECD calibrated with $\mathrm{CH}_{4}: \mathrm{CO}_{2}: \mathrm{N}_{2} \mathrm{O}: \mathrm{N}_{2}$ mixtures (Air Liquide Belgium) of 1 , 10 and $30 \mathrm{ppm} \mathrm{CH}_{4}$ and of $0.2,2.0$ and $6.0 \mathrm{ppm} \mathrm{N}_{2} \mathrm{O}$, and using the solubility coefficients of Yamamoto et al. (1976) for $\mathrm{CH}_{4}$ and Weiss and Price (1980) for $\mathrm{N}_{2} \mathrm{O}$.

Filters $(25 \mathrm{~mm})$ for $\mathrm{POC}$, PN and $\delta^{13} \mathrm{C}_{\mathrm{POC}}$ were decarbonated with $\mathrm{HCl}$ fumes for $4 \mathrm{~h}$, re-dried and packed in $\mathrm{Ag}$ cups. POC, PN and $\delta^{13} \mathrm{C}_{\mathrm{POC}}$ were determined on the abovementioned EA-IRMS using the thermal conductivity detector (TCD) signal of the EA to quantify POC and PN, and by monitoring $m / z 44,45$ and 46 on the IRMS. Internally calibrated acetanilide and sucrose (IAEA-C6) were used to calibrate the $\delta^{13} \mathrm{C}_{\mathrm{POC}}$ data and quantify POC and PN, after taking filter blanks into account. Reproducibility of $\delta^{13} \mathrm{C}_{\mathrm{POC}}$ measurements was better than $\pm 0.2 \%$. Samples for DOC and $\delta^{13} \mathrm{C}_{\mathrm{DOC}}$ were analysed either on a Thermo HiperTOC IRMS (Bouillon et al., 2006), or with an Aurora1030 total
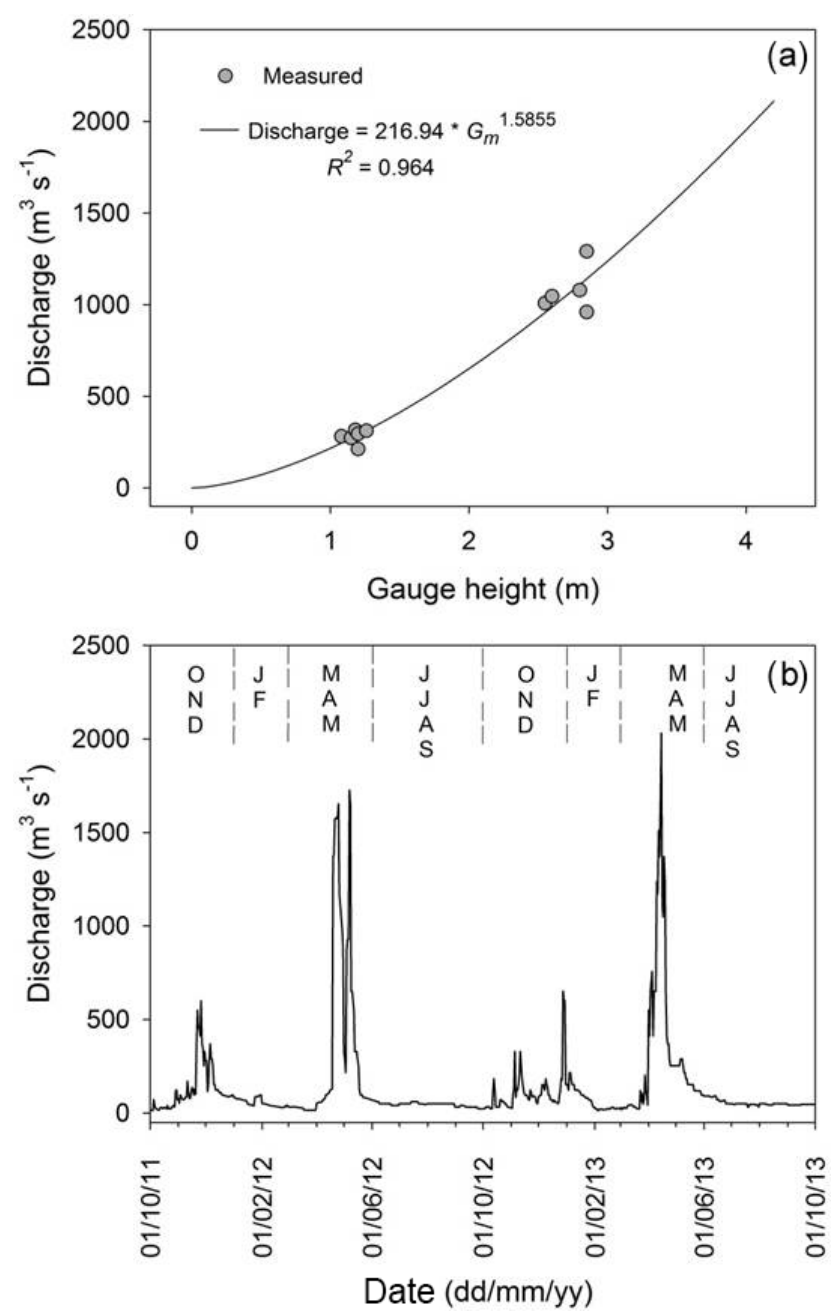

Figure 2. (a) Discharge rating curve for the Sabaki River at the Baricho gauge station (3HA13). (b) Calculated daily discharge for the 2-year monitoring period. Note the one anomalous gauge reading on the 12 November 2012 provides an upper discharge estimate of $41332 \mathrm{~m}^{3} \mathrm{~s}^{-1}$, over a magnitude larger than the next highest daily discharge estimate $\left(3441 \mathrm{~m}^{3} \mathrm{~s}^{-1}\right)$. Given the discharge estimates on the preceding (11 November 2012) and following days (13 November 2012) were 312 and $218 \mathrm{~m}^{3} \mathrm{~s}^{-1}$ respectively and also reported historical maximum daily discharge of $\sim 5000 \mathrm{~m}^{3} \mathrm{~s}^{-1}$ (Delft Hydraulics, 1970), we linearly interpolated the gauge data for the 12 November 2012 from the values of adjacent days thereby lowering the discharge estimate for this date to $249 \mathrm{~m}^{3} \mathrm{~s}^{-1}$. The curve in (a) was developed from the limited dataset $(n=11)$ of recent discharge measurements (2006-2007; grey circles) on the Sabaki River at Baricho (data supplied by WRMA, Machakos).

OC (TOC) analyser (OI Analytical) coupled to a Delta V Advantage IRMS. Typical reproducibility observed in duplicate samples was in most cases $< \pm 5 \%$ for DOC, and $\pm 0.2 \%$ ofor $\delta^{13} \mathrm{C}_{\mathrm{DOC}}$.

Our dataset for $\mathrm{CH}_{4}$ and $\mathrm{N}_{2} \mathrm{O}$ has been used in a continental-scale data synthesis in Borges et al. (2015a), but is discussed here in more detail. 


\subsection{Discharge estimates}

Historical discharge observations and daily gauge height data for the sampling period were provided by the Water Resource Management Authority (WRMA), Machakos, Kenya. Due to the poor resolution of discharge and gauge data at the Sabaki Bridge north of Malindi (gauge no. 3HA06) over the monitoring period, the finer fidelity record from the Baricho station (gauge no. 3HA13) was used, situated approximately $50 \mathrm{~km}$ upstream of our biogeochemical monitoring station (i.e. site S20 from basin-wide sampling campaigns; see Marwick et al., 2014a). With discharge measurements from 2006 and $2007(n=11)$, care of WRMA, we developed a rating curve to calculate daily discharge from available gauge data (Fig. 2a). As seen in Fig. 2a, the limited and poor spread of discharge measurements results in extrapolation for gauge heights $<1$ and $>3 \mathrm{~m}$. Although Kenyan rivers have been suggested to export up to $80 \%$ of annual sediment load during pulse discharge events over few days (Dunne, 1979), the time frame of these event pulses is typically shortlived relative to more typical flow conditions, and at heights for example $<3 \mathrm{~m}$ (which account for $\sim 97 \%$ of gauge data) we have reasonable confidence that the rating curve reflects in situ conditions. Given the general positive correlation between discharge and sediment concentration, and disregarding possible hysteresis in discharge-sediment flux dynamics (which have been shown for the neighbouring Tana River), we suspect the greatest error in our discharge estimates is when gauge height exceeds $3 \mathrm{~m}$.

The Baricho gauge height dataset contains a 2-month period of no measurements (1 February to 31 March 2013). For this period, the daily discharge was estimated as the average discharge for that day over the previous 10 years (20032012). Since this period falls within the dry season when flows are relatively stable and low, we expect any bias deriving from this approximation to have no major effect on our annual flux estimates.

\subsection{Suspended sediment and $C, N$ and $P$ flux estimates}

Annual flux estimates for suspended sediments and the various riverine fractions of particulate and dissolved $\mathrm{C}, \mathrm{N}$ and $\mathrm{P}$ were calculated with the discharge data above. We interpolated linearly between the concentrations measured on consecutive sampling dates in order to establish concentrations for every day of the study period. The daily concentrations were then multiplied by daily discharge and summed over the study period to establish annual flux estimates.

\section{Results}

\subsection{Discharge}

All data (excluding results for $\mathrm{NH}_{4}{ }^{+}, \mathrm{NO}_{3}{ }^{-}$and $\mathrm{PO}_{4}{ }^{3-}$ ) are presented for the period between October 2011 and September 2013, encompassing two full seasons each of short wet
(October-December; OND), short dry (January-February; JF), long wet (March-May; MAM) and long dry (JuneSeptember; JJAS). Over the monitoring period, daily discharge (Fig. 2b; see also Table S1 in the Supplement) varied between 13 and $2032 \mathrm{~m}^{3} \mathrm{~s}^{-1}$, with mean and median flow rates of 139 and $51 \mathrm{~m}^{3} \mathrm{~s}^{-1}$ respectively compared to the average flow rate of $73 \mathrm{~m}^{3} \mathrm{~s}^{-1}$ reported by Kitheka (2013) for 2001-2003 and noted as a relatively wet period. The average annual discharge throughout the monitoring period totalled $\sim 4.4 \mathrm{~km}^{3}$, considerably less than the $\sim 10.7 \mathrm{~km}^{3}$ used by Mayorga et al. (2010) and approximately double that reported by Kitheka $\left(2013 ; \sim 2.3 \mathrm{~km}^{3}\right)$ for the period $2001-$ 2003. There was negligible inter-annual variation of total discharge for the monitoring period. Discharge during the wet seasons (MAM + OND) accounted for 82 and $79 \%$ of annual discharge for 2011-2012 and 2012-2013 respectively while 59 and $51 \%$ of annual discharge occurred during the upper $10 \%$ of daily flows for the same periods.

Throughout the results and discussion we use discharge values of $\leq 68 \mathrm{~m}^{3} \mathrm{~s}^{-1}$ and $\geq 152 \mathrm{~m}^{3} \mathrm{~s}^{-1}$ when referring to low and high flow (hereafter LF and HF) conditions respectively, corresponding to the maximum value for the upper $80 \%$ of daily dry season flows and minimum value for the upper $30 \%$ of daily wet season flows.

\subsection{Physico-chemical parameters}

Water temperature varied from 24.1 to $33.9^{\circ} \mathrm{C}$ (average $\pm 1 \mathrm{SD}=29.8 \pm 2.0^{\circ} \mathrm{C}$ ), with considerable variability intraand inter-seasonally. The coolest temperatures occurred at the end of the MAM wet season and during the JJAS dry season. $\mathrm{pH}$ varied widely across the sampling period (range $=4.6$ to 10.1 ) yet maintained an average of $7.1 \pm 1.1$. Most basic conditions were typically observed during lower-flow periods of the dry seasons. $\% \mathrm{O}_{2}$ saturation ranged between 23.3 and $130.0 \%$, with least saturated conditions observed during the JJAS dry season of 2013. There was no clear relationship between discharge and conductivity, with the latter's range varying sporadically over the sampling period from 113.0 to $1080.0 \mu \mathrm{S} \mathrm{cm}^{-1}$ (average $=487.1 \pm 254.5 \mu \mathrm{S} \mathrm{cm}^{-1}$ ). Total alkalinity (TA) varied over an order of magnitude $\left(0.475\right.$ to $\left.4.964 \mathrm{mmol} \mathrm{kg}^{-1}\right)$ with an average of $2.438 \pm 0.872 \mathrm{mmol} \mathrm{kg}^{-1}$. There was poor correlation between discharge and $\mathrm{TA}$, with observed peaks scattered across the hydrograph, suggesting a simple two source scenario of baseflow and high-flow dilution is inadequate to explain the seasonal variability for the A-G-S system. All data for physico-chemical parameters and those outlined below are presented in Table S1 of the Supplement.

\subsection{Bulk concentrations}

The concentrations of TSM, POC, particulate N (PN) and total particulate phosphorus (TPP) are shown in Fig. 3, as well as the stable isotope composition of POC and PN, 

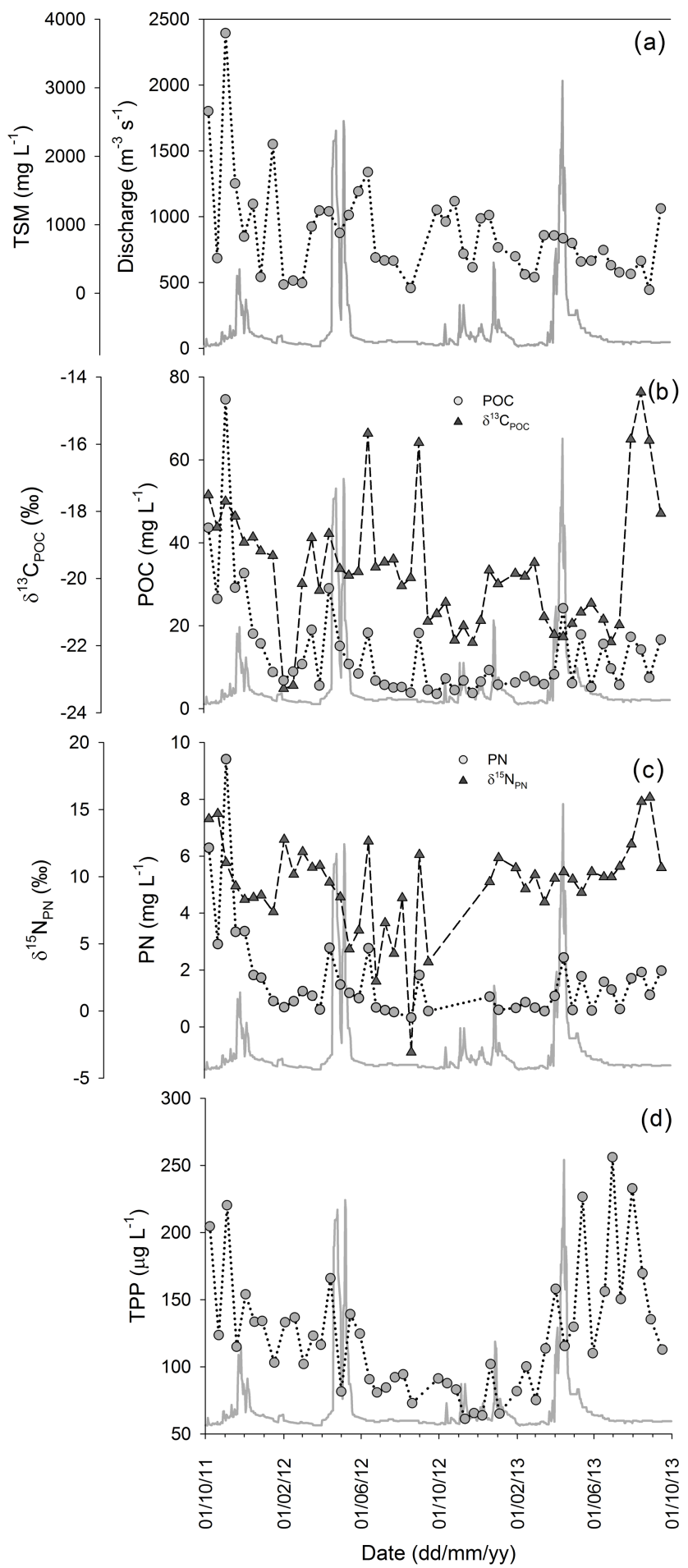

Figure 3. Discharge (solid grey line) and 2 years of monitoring the (a) total suspended matter concentration, the concentration and stable isotope signature of (b) particulate organic carbon and (c) particulate nitrogen and the concentration of (d) total particulate phosphorus in the Sabaki River. In all figures grey circles represent bulk concentrations and dark triangles represent stable isotope signatures. with most variables showing no pronounced relationships with discharge across the hydrological year. The Sabaki River exported TSM varying in concentration from 50.0 to $3796.7 \mathrm{mg} \mathrm{L}^{-1}$ (Fig. 3a), containing POC at concentrations between 3.5 and $74.6 \mathrm{mg} \mathrm{L}^{-1}$ (Fig. 3b). The lower and upper TSM and POC concentrations were associated with the JJAS (dry) and OND (wet) periods of 2011 respectively. The contribution of POC to the TSM pool (hereafter \%POC) indicates a wide biannual variation in suspended sediment load from OC poor $(0.3 \%)$ to OC rich $(14.9 \%)$, with the highest \%POC occurring when discharge is $<100 \mathrm{~m}^{3} \mathrm{~s}^{-1}$ (Fig. 4a) and at lower TSM concentrations (Fig. 4b). The large range for the $\mathrm{C}$ stable isotope $\left(\delta^{13} \mathrm{C}\right)$ of the POC pool $\left(\delta^{13} \mathrm{C}_{\mathrm{POC}} ;-23.3\right.$ to $-14.5 \%$ ) displayed complex temporal patterns with no obvious trends across seasons or with discharge (Fig. 3b). Particulate $\mathrm{N}$ ranged in concentration from 0.3 to $9.4 \mathrm{mg} \mathrm{L}^{-1}$ (Fig. 3c), while the ratio of POC to PN (as a weight : weight ratio; hereafter POC: $\mathrm{PN}$ ) varied from 6.6 to 17.4 , with an average value of $9.4 \pm 1.7(n=42)$. The $\mathrm{N}$ stable isotope composition $\left(\delta^{15} \mathrm{~N}\right)$ of PN $\left(\delta^{15} \mathrm{~N}_{\mathrm{PN}}\right)$ showed considerable fluctuation (from -3.1 to $+15.9 \%$; Fig. $3 \mathrm{c}$ ), with the most ${ }^{15} \mathrm{~N}$-enriched PN recorded at the beginning of the OND period of 2011-2012 and during the JJAS period of 2012-2013. The TPP concentrations (Fig. 3d) ranged between 61.2 and $256.1 \mu \mathrm{g} \mathrm{L}^{-1}$ and were not correlated with discharge. Although TPP generally rose during (or slightly preceding) peak discharge, the highest values were recorded under LF conditions during the 2012-2013 JJAS period.

The dissolved organic C (DOC) concentration fluctuated from 3.3 to $9.3 \mathrm{mg} \mathrm{L}^{-1}$ (Fig. 5a), with lowest and highest concentrations observed during the JJAS and MAM periods of 2013 respectively. The highest DOC concentrations were regularly observed in the weeks following wet season peak discharge. The contribution of DOC to the TOC pool ranged between 15 and $68 \%$ (accounting for 20 and $32 \%$ of annual TOC export during 2011-2012 and 2012-2013 respectively) with no clear seasonal trend. Akin to the $\delta^{13} \mathrm{C}_{\mathrm{POC}}$, the $\delta^{13} \mathrm{C}$ composition of the DOC pool $\left(\delta^{13} \mathrm{C}_{\mathrm{DOC}}\right)$ varied widely $(-29.3$ to $-17.9 \%$ o $)$ with no obvious relationship with either seasonality or discharge (Fig. 5a). On average, the DOC was more depleted in ${ }^{13} \mathrm{C}$ than in concurrent POC samples $\left(\delta^{13} \mathrm{C}_{\mathrm{POC}}-\delta^{13} \mathrm{C}_{\mathrm{DOC}}=2.8 \pm 2.9 \%, n=40\right)$.

The $\delta^{13} \mathrm{C}$ composition of the DIC pool $\left(\delta^{13} \mathrm{C}_{\text {DIC }}\right)$ shifted between -12.4 and $-3.2 \%$ (Fig. $5 \mathrm{~b}$ ), and was generally higher during LF periods and lower over the wet seasons.

Sampling of $\mathrm{NH}_{4}{ }^{+}, \mathrm{NO}_{3}{ }^{-}$and $\mathrm{PO}_{4}{ }^{3-}$ was conducted over a different time frame than the rest of the data presented here. The range in daily discharge over this time period (21 December 2012 to 20 December 2013) reflects the ranges reported above for the 2-year discharge record, although the mean flow rate was somewhat elevated $\left(169 \mathrm{~m}^{3} \mathrm{~s}^{-1}\right)$. Total annual discharge was $5.3 \mathrm{~km}^{3}$, with around $83 \%$ of total annual discharge occurring during the wet seasons. The concentration range for $\mathrm{NH}_{4}{ }^{+}, \mathrm{NO}_{3}{ }^{-}$and $\mathrm{PO}_{4}{ }^{3-}$ over the 1-year period were 7.1 to $309.6 \mu \mathrm{mol} \mathrm{L}{ }^{-1}$, 

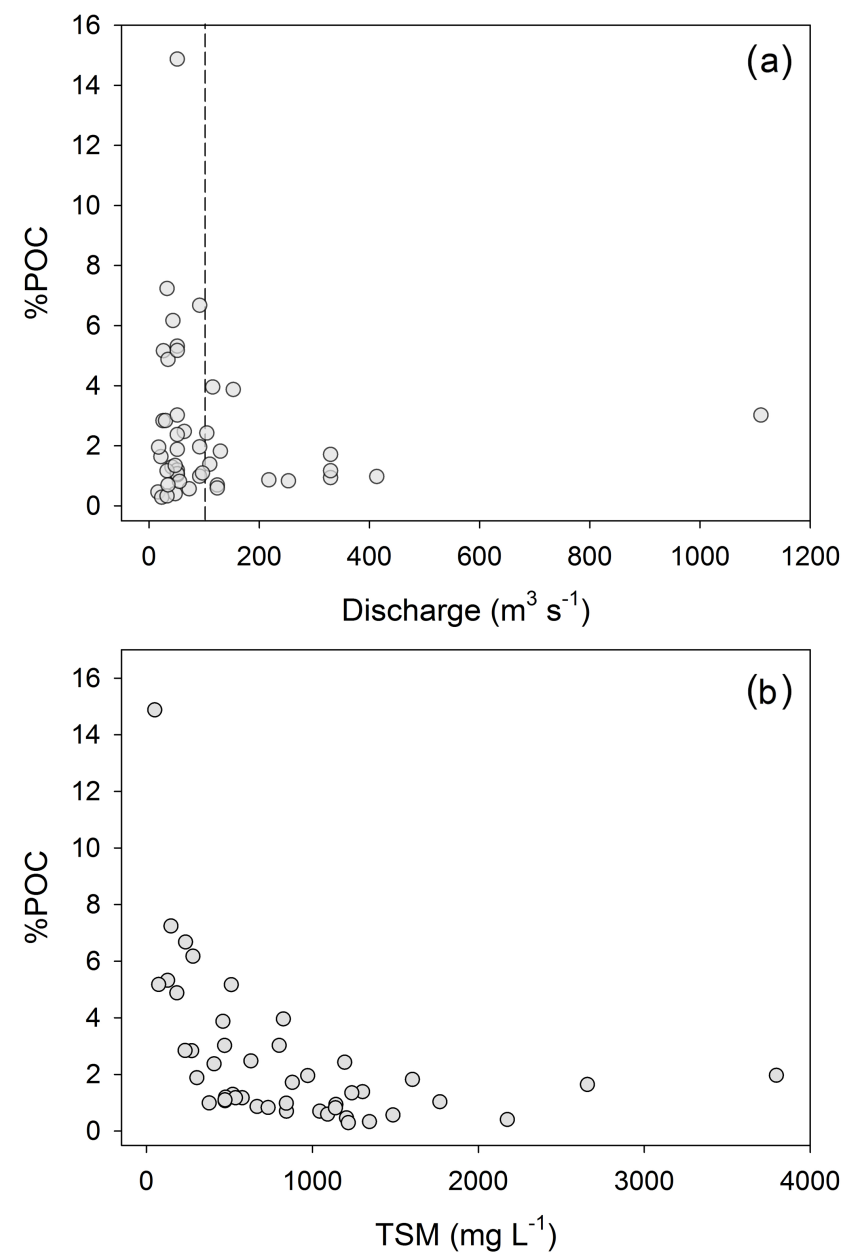

Figure 4. The relationship between the percent contribution of particulate organic carbon to the total suspended load and (a) discharge and (b) total suspended matter. The dashed line in (a) marks discharge of $100 \mathrm{~m}^{3} \mathrm{~s}^{-1}$, as cited in the text.

$<0.1$ to $506.9 \mu \mathrm{mol} \mathrm{L}{ }^{-1}$ and 1.1 to $322.6 \mu \mathrm{mol} \mathrm{L}^{-1}$ respectively (Fig. 6). No clear seasonal pattern is apparent in the dissolved inorganic $\mathrm{N}$ fractions (Fig. 6b, c), although peak concentrations generally occur at below-average discharge conditions (i.e. when $Q<169 \mathrm{~m}^{3} \mathrm{~s}^{-1}$ then the average $\left( \pm 1\right.$ SD) DIN concentration is $172.2 \pm 140.1 \mu \mathrm{mol} \mathrm{L}^{-1}$ $(n=20)$, whereas when $Q \geq 169 \mathrm{~m}^{3} \mathrm{~s}^{-1}$ then the average $\left( \pm 1\right.$ SD) DIN concentration is $59.6 \pm 26.3 \mu \mathrm{mol} \mathrm{L}^{-1}$ $(n=5)$ ). The concentration of $\mathrm{PO}_{4}{ }^{3-}$ (Fig. 6d)was highly variable at below-average flow conditions (i.e. when $Q<169 \mathrm{~m}^{3} \mathrm{~s}^{-1}$ the average ( $\pm 1 \mathrm{SD}$ ) $\mathrm{PO}_{4}{ }^{3-}$ concentration is $\left.105.7 \pm 97.2 \mu \mathrm{mol} \mathrm{L}^{-1}(n=20)\right)$, whereas concentrations became comparatively low during above-average discharge (i.e. when $Q \geq 169 \mathrm{~m}^{3} \mathrm{~s}^{-1}$ then the average $( \pm 1 \mathrm{SD}) \mathrm{PO}_{4}{ }^{3-}$ concentration is $\left.34.8 \pm 31.0 \mu \mathrm{mol} \mathrm{L}^{-1}(n=5)\right)$.

The river was consistently oversaturated in dissolved $\mathrm{CH}_{4}$ relative to the atmosphere (from 499 to $135111 \%$ ) with a concentration range of between 10 and $2838 \mathrm{nmol} \mathrm{L}^{-1}$

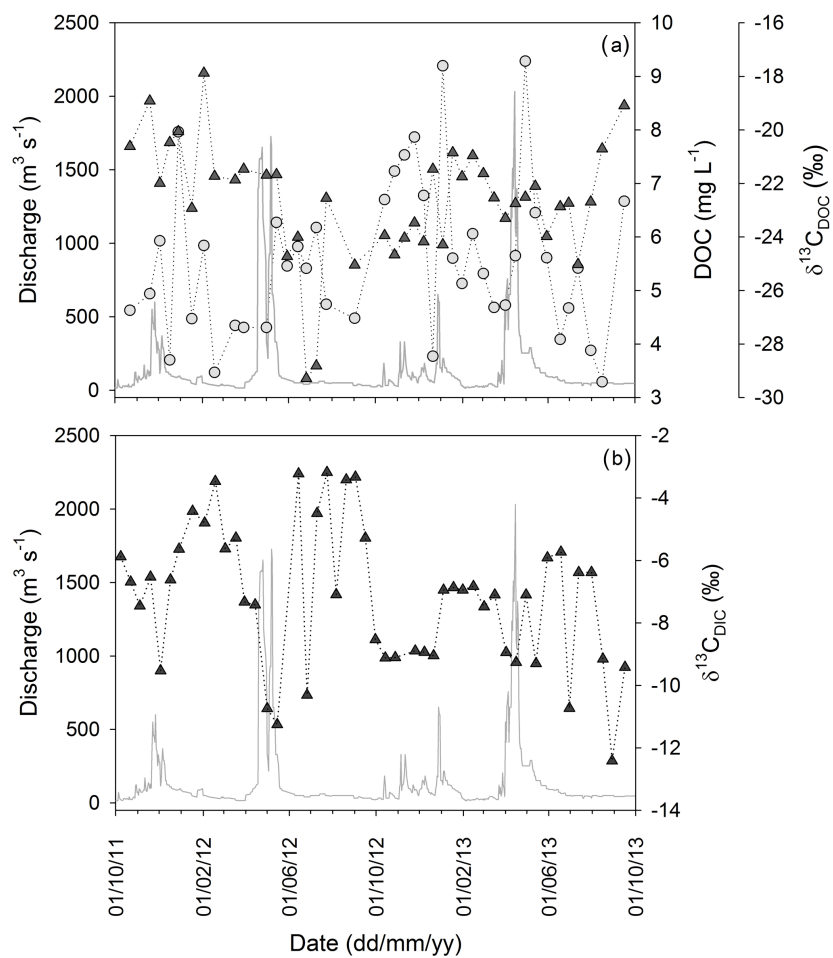

Figure 5. Discharge and 2 years of monitoring the dissolved (a) organic carbon concentration and carbon stable isotope signature, and (b) the carbon stable isotope signature of dissolved inorganic carbon in the Sabaki River. Grey circles represent bulk concentrations, with dark triangles for all stable isotope signatures.

(Fig. 7a). Although $\mathrm{CH}_{4}$ peaks occurred in both dry and wet seasons, the largest annual peaks occur at the end of the JJAS dry period. Concentrations of dissolved $\mathrm{N}_{2} \mathrm{O}$ (Fig. 7b) varied from 5.9 to $26.6 \mathrm{nmol} \mathrm{L}^{-1}$, corresponding to oversaturation of 100 to $463 \%$ relative to atmospheric concentrations. $\mathrm{N}_{2} \mathrm{O}$ concentrations were highest during the OND period of 2011-2012, and otherwise showed maximum concentrations preceding peak discharge during the MAM period of each year.

\subsection{Annual flux and yield of particulate and dissolved fractions}

Annual material flux estimates to the coastal zone for TSM and various $\mathrm{C}, \mathrm{N}$ and $\mathrm{P}$ fractions are provided in Table 1 . Briefly, our data suggest a mean flux of 4.0 Tg TSM yr ${ }^{-1}$,

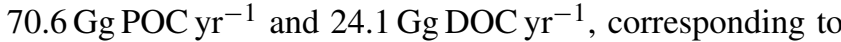
mean annual \%POC of $1.8 \%$, and mean annual contribution of DOC to the TOC pool (hereafter \%DOC) of $26 \%$. Biannually, wet season (OND, MAM) flows carried $>80 \%$ of the total load for TSM $(\sim 86 \%)$, POC $(\sim 89 \%)$ and DOC $(\sim 81 \%)$, with the MAM period accounting for $>50 \%$ of TSM, POC and DOC annual export. Estimates of mean annual flux of PN and TPP were 7.5 and $0.5 \mathrm{Gg}$ respectively, and $>80 \%$ of biannual export of PN $(\sim 89 \%)$ and TPP 

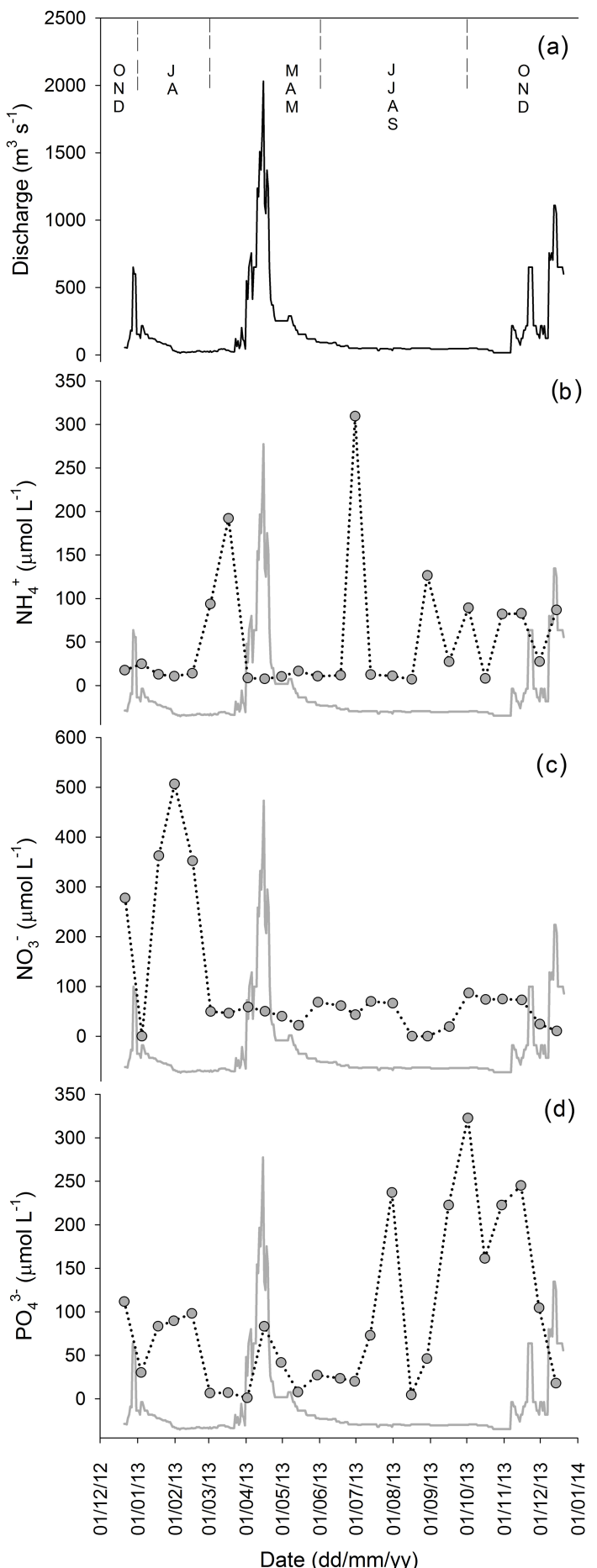

Figure 6. (a) Daily discharge rates and 1 year of monitoring the concentration of dissolved (b) ammonium, (c) nitrate and (d) phosphate in the Sabaki River. In panels (b)-(d) grey circles represent bulk concentrations.

( $\sim 82 \%)$ occurred during the wet seasons, with $>50 \%$ of the annual flux occurring over the MAM period.
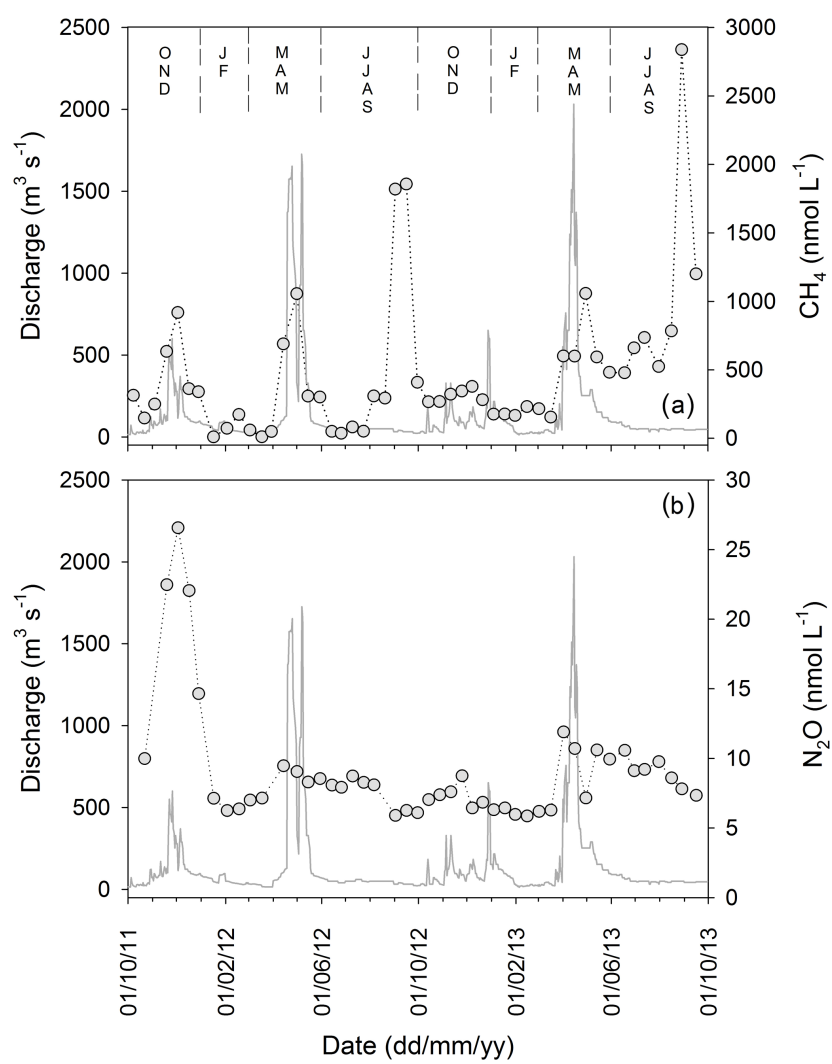

Figure 7. Two years of monitoring concentrations of dissolved (a) methane and (b) nitrous oxide. Grey circles represent riverine gas concentrations.

Annual dissolved nutrient flux estimates (Table 1) were $2.3 \mathrm{Gg} \mathrm{NH}_{4}{ }^{+}, 4.3 \mathrm{Gg} \mathrm{NO}_{3}{ }^{-}$and $11.2 \mathrm{Gg} \mathrm{PO}_{4}{ }^{3-}$. Approximately $75 \%$ of $\mathrm{NH}_{4}{ }^{+}$export occurred during the wet seasons, whereas only $66 \%$ of $\mathrm{NO}_{3}{ }^{-}$export occurred over the same period. Approximately $79 \%$ of annual $\mathrm{PO}_{4}{ }^{3-}$ export took place during the wet seasons, with a greater proportion exported over the OND wet season $(45 \%)$ than the MAM wet season.

Various surface area estimates are reported for the A-G-S Basin, ranging from $40000 \mathrm{~km}^{2}$ (Giesen and van de Kerkhof, 1984; van Katwijk et al., 1993), to $\sim 70000 \mathrm{~km}^{2}$ (Fleitmann et al., 2007; Kitheka, 2013), and up to $117000 \mathrm{~km}^{2}$ by Mayorga et al. (2010). Using ArcGIS 10.1 and the African river basin output of Lehner et al. (2006; http://hydrosheds. cr.usgs.gov), we estimate the A-G-S Basin covers an area of $\sim 46750 \mathrm{~km}^{2}$

Taking the above basin area estimate and the flux values detailed above, we estimate mean annual yields of $84.6 \mathrm{Mg} \mathrm{TSM} \mathrm{km}^{-2}, \quad 1.51 \mathrm{Mg}$ POC $\mathrm{km}^{-2}$ and $0.52 \mathrm{Mg} \mathrm{DOC} \mathrm{km}^{-2}$ (Table 1). Conservative mean annual yields for particulate nutrient forms $161 \mathrm{~kg} \mathrm{PN} \mathrm{km}^{-2}$ and $11 \mathrm{~kg} \mathrm{TPP} \mathrm{km}^{-2}$, while those of the dissolved fractions over the single hydrological year were $49 \mathrm{~kg} \mathrm{NH}_{4}{ }^{+} \mathrm{km}^{-2}$, 
Table 1. Summary of annual fluxes, element ratios and annual yields for the Athi-Galana-Sabaki River basin from data reported here and from the NEWS2 export model (see Mayorga et al., 2010), as well as data for 2012 and 2013 from the neighbouring Tana River basin at Garsen (Geeraert et al., 2018).

\begin{tabular}{|c|c|c|c|}
\hline & A-G-S & $\begin{array}{r}\text { A-G-S } \\
(\text { NEWS2) }\end{array}$ & Tana \\
\hline \multicolumn{4}{|l|}{ Fluxes } \\
\hline Basin area $\left(\mathrm{km}^{2}\right)$ & 46750 & 117230 & 81700 \\
\hline Discharge $\left(\mathrm{km}^{3} \mathrm{yr}^{-1}\right)$ & $4.39^{\mathrm{a}}$ & 10.75 & $4.32-4.71$ \\
\hline Discharge $\left(\mathrm{km}^{3} \mathrm{yr}^{-1}\right)$ & $5.32^{b}$ & & \\
\hline $\operatorname{TSM}\left(\operatorname{Tg~yr}^{-1}\right)$ & 4.0 & 38.8 & $4.1-4.9$ \\
\hline POC $\left(\mathrm{Gg} \mathrm{yr}^{-1}\right)$ & 70.6 & 205.3 & $113-157$ \\
\hline $\operatorname{DOC}\left(\mathrm{Gg} \mathrm{yr}^{-1}\right)$ & 24.1 & 49.5 & $11-14$ \\
\hline $\mathrm{PN}\left(\mathrm{Gg} \mathrm{yr}^{-1}\right)$ & 9.4 & 16.4 & \\
\hline $\mathrm{TPP}\left(\mathrm{Gg} \mathrm{yr}^{-1}\right)$ & 0.5 & 9.6 & \\
\hline DIN & 6.6 & 7.4 & \\
\hline $\mathrm{PO}_{4}{ }^{3-}\left(\mathrm{Gg} \mathrm{yr}^{-1}\right)$ & 11.2 & 0.9 & \\
\hline$\% \mathrm{POC}$ ( of TSM) & 1.8 & 0.5 & \\
\hline POC : PN & 8.7 & 12.5 & \\
\hline$\%$ DOC (of TOC) & 25.5 & 23.0 & \\
\hline \multicolumn{4}{|l|}{ Yields } \\
\hline $\operatorname{TSM}\left(\mathrm{Mg} \mathrm{km}^{-2} \mathrm{yr}^{-1}\right)$ & 84.6 & 330.7 & $50.2-60.0$ \\
\hline $\operatorname{POC}\left(\mathrm{Mg} \mathrm{km}^{-2} \mathrm{yr}^{-1}\right)$ & 1.51 & 1.75 & $1.38-1.92$ \\
\hline $\operatorname{DOC}\left(\mathrm{Mg} \mathrm{km}^{-2} \mathrm{yr}^{-1}\right)$ & 0.52 & 0.42 & $0.13-0.17$ \\
\hline $\mathrm{PN}\left(\mathrm{kg} \mathrm{km}^{-2} \mathrm{yr}^{-1}\right)$ & 161 & 140 & \\
\hline $\operatorname{TPP}\left(\mathrm{kg} \mathrm{km}^{-2} \mathrm{yr}^{-1}\right)$ & 11 & 82 & \\
\hline $\mathrm{DIN}\left(\mathrm{kg} \mathrm{km}^{-2} \mathrm{yr}^{-1}\right)$ & 142 & 63 & \\
\hline $\mathrm{PO}_{4}{ }^{3-}\left(\mathrm{kg} \mathrm{km}^{-2} \mathrm{yr}^{-1}\right)$ & 239 & 8 & \\
\hline
\end{tabular}

a All fractions except dissolved $\mathrm{N}$ and P: hydrological years 1 October 2011 to 30 September 2012 and 1 October 2012 to 30 September 2013.

b Dissolved N and P only: hydrological year 21 December 2012 to 14 December 2013.

$93 \mathrm{~kg} \mathrm{NO}_{3}{ }^{-} \mathrm{km}^{-2}$ and $239 \mathrm{~kg} \mathrm{PO}_{4}{ }^{3-} \mathrm{km}^{-2}$ (see also Table S2 in the Supplement).

\section{Discussion}

Although previous studies provide estimates of annual suspended sediment fluxes at the Sabaki outlet as well as annual yield estimates for the A-G-S Basin (GOK-TARDA, 1981; Munyao et al., 2003; Kitheka, 2013), their primary research focus lay elsewhere, and none provide the comprehensive biogeochemical record at a comparable temporal scale as presented here. The following discussion revolves around the main objectives of our study, including (i) the quantification of annual suspended matter, $\mathrm{C}, \mathrm{N}$ and $\mathrm{P}$ fluxes and sediment yield, (ii) characterising the sources of particulate and dissolved fractions of $\mathrm{C}$ and $\mathrm{N}$ and (iii) providing indications to the water-atmosphere transfer of important greenhouse gases $\left(\mathrm{CH}_{4}\right.$ and $\left.\mathrm{N}_{2} \mathrm{O}\right)$ at the outlet of the Sabaki River. We con- clude with consideration of the future anthropogenic impacts in the A-G-S Basin and the consequences for material fluxes from the Sabaki River to the coastal zone.

\subsection{Material fluxes, annual yields and their origin}

To the best of our knowledge, and excluding suspended matter, the estimates provided in Table 1 are the first quantifications of material fluxes from the A-G-S system, although we stress that our material flux estimates may not be the most robust since (i) hydrological data are incomplete and discharge data rely on an limited number of measurements to construct a rating curve and (ii) our study covered a period of 2 years, while annual discharge in this system is likely to show substantial interannual variability. A suspended sediment flux of $\sim 7.5$ to $14.3 \mathrm{Tg} \mathrm{yr}^{-1}$ is commonly cited for the A-G-S system (Watermeyer et al., 1981; van Katwijk et al., 1993; Fleitmann et al., 2007), which is approximately 2- to 3.5 -fold greater than our conservative flux estimate of $\sim 4.0 \mathrm{Tg} \mathrm{TSM} \mathrm{yr}{ }^{-1}$. A more recent estimate from Kitheka (2013) for the period 2001-2003 $\left(5.7 \mathrm{Tg} \mathrm{yr}^{-1}\right)$ is still greater than, though more comparable to, our own estimate above. While we employed year-round biweekly monitoring and extrapolated fluxes from daily gauge height readings, Kitheka (2013) measured concurrent discharge and suspended matter concentrations at monthly to biweekly periodicity. The relative coarseness of sampling interval employed by Kitheka (2013), in combination with their acknowledgement that peak sediment flux often occurs prior to peak discharge, i.e. sediment exhaustion effect (Rovira and Batalla, 2006; Oeurng et al., 2011; Tamooh et al., 2014), may preempt accurate extrapolation of the annual sediment flux from their limited dataset. For example, in order to accurately estimate fluxes in systems with an irregular hydrograph, such as the neighbouring Tana River (which experiences climatic conditions and annual hydrograph pattern similar to the A-G-S Basin), monitoring at a recurrence interval of $<7$ days has been recommended (Tamooh et al., 2014), also implying that the flux estimates presented here may be improved with a more refined sampling frequency.

If we normalise the basin area of $\sim 70000 \mathrm{~km}^{2}$ reported by Fleitmann et al. (2007) and Kitheka (2013) to the value reported here $\left(\sim 46750 \mathrm{~km}^{2}\right)$, and subsequently recalculate their SY from their riverine sediment flux values, we find our SY of $\sim 85 \mathrm{Mg} \mathrm{km}^{-2} \mathrm{yr}^{-1}$ is considerably lower than the 160 to $306 \mathrm{Mg} \mathrm{km}^{-2} \mathrm{yr}^{-1}$ recalculated from Fleitmann et al. (2007) and the $122 \mathrm{Mg} \mathrm{km}^{-2} \mathrm{yr}^{-1}$ from Kitheka (2013).

Some have reported that prior to 1960 the suspended sediment load of the A-G-S Basin was $\sim 58 \mathrm{Gg} \mathrm{yr}^{-1}$ (Watermeyer et al., 1981; Van Katwijk et al., 1993), which is equivalent to an $\mathrm{SY}$ of $\sim 1 \mathrm{Mg} \mathrm{km}^{-2} \mathrm{yr}^{-1}$. Although indeed the A-G-S Basin has been disturbed by anthropogenic practices since European arrival, this value needs to be met with some scepticism, as it represents an approximately 85-fold increase in annual soil loss over the past 50 years. In the neigh- 
bouring Tana River basin, Tamooh et al. (2014) estimated annual suspended sediment yields between 46 and $48 \mathrm{Mg} \mathrm{km}^{-2}$ at $\sim 150 \mathrm{~km}$ from the river mouth (basin area of $66500 \mathrm{~km}^{2}$ ). More recently, the higher-resolution dataset of Geeraert et al. (2018; see Table 1) for the Tana River at Garsen $(\sim 70 \mathrm{~km}$ from the river mouth, basin area of $81700 \mathrm{~km}^{2}$ ) estimated a suspended SY of $50-60 \mathrm{Mg} \mathrm{km}^{-2}$, indicating that the relatively smaller A-G-S Basin exports a comparable quantity of sediment annually to the coastal zone to that discharged from the much larger (and heavily regulated) Tana River basin.

The SY reported here is low compared to the global average of $190 \mathrm{Mg} \mathrm{km}^{-2} \mathrm{yr}^{-1}$ (Milliman and Farnsworth, 2011) and considerably less than the average of $634 \mathrm{Mg} \mathrm{km}^{-2} \mathrm{yr}^{-1}$ for the African continent recently reported by Vanmaercke et al. (2014). This may be somewhat surprising given the typically concentrated suspended sediment loads observed over the monitoring period (mean $( \pm 1 \mathrm{SD})=865 \pm 712 \mathrm{mg} \mathrm{L}^{-1}$; median $=700 \mathrm{mg} \mathrm{L}^{-1}$ ), but can be explained by the fact all TSM concentrations $>1500 \mathrm{mg} \mathrm{L}^{-1}$ were observed at below HF discharge rates (i.e. $<152 \mathrm{~m}^{-3} \mathrm{~s}^{-1}$; see Fig. 3a). All the same, our SY estimate is over 3-fold greater than the average pre-dam SY of $25 \mathrm{Mg} \mathrm{km}^{-2} \mathrm{yr}^{-1}$ from the Congo, Nile, Niger, Zambezi and Orange rivers (draining $>40 \%$ of the African landmass; Milliman and Farnsworth, 2011). Sediment yield estimates from other arid tropical basins of Africa (e.g. Gambia, Limpopo, Niger, and Senegal rivers) are significantly lower (between 3 and $18 \mathrm{Mg} \mathrm{km}^{-2} \mathrm{yr}^{-1}$; Milliman and Farnsworth, 2011), although reported yields of $94 \mathrm{Mg} \mathrm{km}^{-2} \mathrm{yr}^{-1}$ from the Rufiji (Tanzania) and $88 \mathrm{Mg} \mathrm{km}^{-2} \mathrm{yr}^{-1}$ from the Ayensu (Ghana), both arid tropical basins, are equivalent to what was observed in the A-G-S Basin.

The annual POC yield $\left(1.5 \mathrm{MgPOC} \mathrm{km}^{-2}\right)$ from the A-G-S Basin is equivalent to the global average of $1.6 \mathrm{Mg} \mathrm{POC} \mathrm{km}^{-2}$ (Ludwig et al., 1996), though almost triple the estimate of $0.6 \mathrm{MgPOC} \mathrm{km}^{-2}$ by Tamooh et al. (2014) at their most downstream site on the neighbouring Tana River, and over 7-fold greater than the $0.2 \mathrm{Mg} \mathrm{POC} \mathrm{km}^{-2}$ reported from the largely pristine, wooded savannah-dominated Oubangui River (Bouillon et al., 2014), the second largest tributary to the Congo River. The over-riding influence of sewage inputs on the biogeochemistry of the A-G-S Basin has been previously brought to attention by Marwick et al. (2014a), partially through investigation of the $\delta^{15} \mathrm{~N}$ composition of the PN pool. The average $\delta^{15} \mathrm{~N}_{\mathrm{PN}}$ recorded across the monitoring period here was $9.5 \pm 3.5 \%$ o $(n=43)$, which sits above the 75th percentile of measurements within other African basins (see Fig. 10 in Marwick et al., 2014a), and reflects the range of $\delta^{15} \mathrm{~N}$ signatures of $\mathrm{NH}_{4}{ }^{+}$(+7 to $+12 \%$; Sebilo et al., 2006) and $\mathrm{NO}_{3}{ }^{-}$(+8 to $+22 \%$; Aravena et al., 1993; Widory et al., 2005 ) sourced from raw waste discharge. As highlighted earlier, around $50 \%$ of Nairobi's population of 3 million live in slums with inadequate waste management facilities which leads to increasing water quality issues (Dafe, 2009; Kithiia and Wambua, 2010), providing an evident explanation for the POC-loaded sediment flux from the A-G-S Basin in comparison to other African river basins.

The annual DOC yield from the A-G-S Basin $\left(0.5 \mathrm{Mg} \mathrm{DOC} \mathrm{km}{ }^{-2}\right)$ is markedly lower than the global

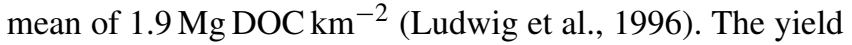
is within the range of 0.1 to $0.6 \mathrm{MgDOC} \mathrm{km}{ }^{-2}$ reported for the Tana River (Tamooh et al., 2014), consistent with the global observation of low DOC concentrations in rivers of semi-arid regions (Spitzy and Leenheer, 1991), and also falls between observations in tropical savannah basins of $\sim 0.3 \mathrm{Mg} \mathrm{DOC} \mathrm{km}{ }^{-2}$ for the Gambia River (Lesack et al., 1984) and $\sim 0.9 \mathrm{MgDOC} \mathrm{km}{ }^{-2}$ for the Paraguay River (Hamilton et al., 1997). Tamooh et al. (2014) attributed the low DOC yield in the Tana basin to low soil OC content (average of $3.5 \pm 3.9 \% \mathrm{OC}$ ) as well as high temperatures in the lower basin (Tamooh et al., 2012, 2014). Surface soils $(0-5 \mathrm{~cm})$ in the A-G-S Basin were of low OC content also, ranging between 0.4 and $8.9 \%$ OC with an average value of $2.0 \pm 1.9 \% \quad(n=19$; own unpublished data), although due to site selection, samples were not gathered from the relatively OC-rich soils of the upper A-G-S Basin (see https://maps.qed.ai/ (last access: 16 March 2018) and the soil organic carbon mean-depth $0-5 \mathrm{~cm}$ overlay).

In contrast to some other $\mathrm{C}_{4}$-rich tropical and sub-tropical river basins, the POC load in the Sabaki River (average $\delta^{13} \mathrm{C}=-19.7 \pm 1.9 \%$ o) is marginally enriched in ${ }^{13} \mathrm{C}$ compared to the basin-wide bulk vegetation $\delta^{13} \mathrm{C}$ value of $-21.0 \%$, as estimated from the crop-corrected vegetation isoscape of Africa in Still and Powell (2010; Fig. 1c). A consistent underrepresentation of $\mathrm{C}_{4}$-derived $\mathrm{C}$ in riverine OC pools was reported in the $\mathrm{C}_{4}$-dominated Betsiboka River basin of Madagascar (Marwick et al., 2014b), the Congo Basin (particularly during dry season, Mariotti et al., 1991; Bouillon et al., 2012), the Amazon Basin (Bird et al., 1992) and in rivers of Australia (Bird and Pousai, 1997) and Cameroon (Bird et al., 1994 and 1998). The relatively low $C_{4}$ contributions in these rivers has typically been attributed to a greater portion of riverine $\mathrm{OC}$ sourced from the neighbouring $\mathrm{C}_{3}$-rich riparian zone relative to more remote $\mathrm{C}_{4}$-dominated landscapes (i.e. grassland/savannah). Under this scenario, the $\mathrm{C}_{4}$-derived riverine $\mathrm{OC}$ component generally peaks during the wet season in response to the increased mobilisation of surface and sub-surface OC stocks from more distant $\mathrm{C}_{4}$ rich sources. At the outlet of the A-G-S Basin, on the other hand, not only was POC more enriched in ${ }^{13} \mathrm{C}$ (peak value of $-14.5 \%$ o) than values recorded in the neighbouring Tana Basin (-19.5\%o; Tamooh et al., 2014) and the $\mathrm{C}_{4}$-dominated Betsiboka Basin (-16.2\%o; see Marwick et al, 2014b), but these ${ }^{13} \mathrm{C}$-enriched POC loads occurred during consecutive JJAS periods (i.e. long dry season), and therefore, an alternative mechanism to the "riparian zone effect" outlined above is required to explain these dry season observations. One possibility is herbivore-mediated inputs of $\mathrm{C}_{4}$-derived organic material $(\mathrm{OM})$ to riverine $\mathrm{OC}$ pools, such as from 
livestock or large native African mammals, as has been reported for Lake Naivasha (Grey and Harper, 2002) and the Mara River in Kenya (Masese et al., 2015). The combined Tsavo West and Tsavo East national parks, accounting for approximately $4 \%$ of the total surface area of Kenya, are dissected by the Galana River downstream of the confluence of the Tsavo with the Athi River. These national parks contain large populations of mammalian herbivores (Ngene et al., 2011), including elephants and buffalo (Fig. S1a and b in the Supplement), which graze on the $\mathrm{C}_{4}$ savannah grasses and gravitate towards perennial water sources, such as the Galana River, during the dry season. More importantly, hippopotami (Fig. S1c in the Supplement) graze within the $\mathrm{C}_{4}$-rich savannas by night and excrete partially decomposed $\mathrm{OM}$ into the river during the day. Grey and Harper (2002) estimated the total quantity of excrement for the Lake Naivasha hippopotamus population to be $\sim 5.8 \mathrm{Gg} \mathrm{yr}^{-1}$ ( $\sim 500$ individuals), assuming a consumption of $40 \mathrm{~kg}$ of biomass and a measured maximum wet weight of $8 \mathrm{~kg}$ of excrement on land per individual per night, with the remainder excreted into the lake during the day. This equates to approximately $\sim 12 \mathrm{Mg} \mathrm{yr}^{-1}$ per hippopotamus, and using the mean excrement compositions from Grey and Harper (2002) of $37 \%$ carbon and $1.5 \%$ nitrogen, results in hippopotamus-mediated delivery of $\sim 740 \mathrm{~kg} \mathrm{Cyr}^{-1}$ and $\sim 30 \mathrm{~kg} \mathrm{Nyr}^{-1}$. To a lesser extent, additional terrestrial subsidies would be supplied by livestock using the river as a water source (Fig. S1d in the Supplement). Aerial census results from 2011 identified $\sim 80$ hippopotami within the combined Tsavo East (i.e. Athi and Galana rivers) and Tsavo West (i.e. Tsavo River) national parks, considerably less than the $\sim 4000$ reported from the Masai Mara National Reserve where the research of Masese et al. (2015) was conducted. Figure S1 in the Supplement highlights the high density of other large mammals congregating around the Athi and Galana rivers, and though a smaller proportion of their total excrement will be released directly to the river relative to hippopotami, the combined quantity may make a significant contribution to the riverine OC pool under low-flow conditions. Hence, it is reasonable to assume these herbivores deliver significant quantities of $\mathrm{C}_{4}$-derived $\mathrm{OM}$ to inland waterways, especially during the dry season when other local water sources are depleted, with this being a time when the inputs may be particularly noticeable in riverine $\delta^{13} \mathrm{C}_{\mathrm{POC}}$ signatures, as the contribution from other allochthonous sources would be minimised (especially $\mathrm{C}_{4}$ derived OM; see Marwick et al., 2014b) due to lower terrestrial runoff rates. The correlation between minor peaks in bulk POC and ${ }^{13} \mathrm{C}$-enriched $\delta^{13} \mathrm{C}_{\mathrm{POC}}$ signatures during the JJAS period of 2012 supports this suggestion, when without a simultaneous increase in discharge, a short pulse of $\mathrm{C}_{4}$ derived OC is observed in the Sabaki River.

The findings from the basin-wide campaigns reported in Marwick et al. (2014a) led to the suggestion that the concentration of DIN in export from the A-G-S Basin likely peaks during the wet season, due to the significant processing and removal of DIN in the upper to mid-basin during the dry season and which resulted in significantly lower DIN concentration at the monitoring station (i.e. site S20 from Marwick et al., 2014a) relative to wet season observations. Our higherresolution dataset, however, suggests a more complex relationship between DIN concentrations, seasonality and discharge, given that peak DIN concentrations were also observed during low-flow conditions (Fig. 6b, c). In particular, a prominent $\mathrm{NH}_{4}{ }^{+}$peak during the JJAS dry season of 2013 occurred in conjunction with peaks in POC and PN, and might be attributed to in situ processing of the dry season organic matter inputs from large herbivores in the lower basin, as outlined above. Similarly, a prominent peak in $\mathrm{NO}_{3}{ }^{-}$was observed during the JF dry season, for which no clear explanation exists. Despite this, our flux estimates suggest that the annual DIN and PN export predominantly occurs during the wet seasons as a result of the elevated discharge conditions, and with the consistent enrichment of the PN pool in ${ }^{15} \mathrm{~N}$ (Fig. 3d) relative to the $\delta^{15} \mathrm{~N}$ composition of biologically fixed $\mathrm{N}$ (i.e. $\sim 0$ to $+2 \%$ ), this supports the analysis of Marwick et al. (2014a) that anthropogenic inputs impart significant influence on the cycling of $\mathrm{N}$ in the A-G-S Basin and the export budget of $\mathrm{N}$ from the Sabaki River to the coastal zone.

The Global Nutrient Export from Watersheds 2 (NEWS2; see Mayorga et al., 2010) provides flux and yield estimates for TSM and particulate and dissolved fractions of organic and inorganic forms of $\mathrm{C}, \mathrm{N}$ and $\mathrm{P}$ for $>6000$ river basins through hybrid empirical and conceptual based models relying on single and multiple linear regressions and singleregression relationships. Comparatively, our flux estimates are in general considerably lower than the NEWS2 estimates (Table 1), except for the dissolved $\mathrm{PO}_{4}{ }^{3-}$ pool. There are at least three likely explanations for these overestimates. Firstly, the basin area used in NEWS2 calculations is 2.5fold greater than our estimate, and given the flux estimates of Mayorga et al. (2010) are also a function of basin area, it is understandable there will be considerable overestimation by the model. Secondly, the TSM sub-model is grounded in datasets of observed conditions (generally not impacted by extensive damming) and independent factors including precipitation, a relief index, dominant lithology, wetland rice and marginal grassland extent, whereas the export of particulate forms of $\mathrm{C}, \mathrm{N}$ and $\mathrm{P}$ are reliant on empirical relationships between contents of TSM and POC (Ludwig et al., 1996) and POC and PN (Ittekkot and Zhang, 1989), and a relationship for particulate phosphorus export based on POC load developed by Beusen et al. (2005). We suggest these relationships may not extrapolate well to a basin so severely impacted by anthropogenic inputs as the A-G-S system. Thirdly, export of dissolved fractions is built upon an empirical dataset of 131 global river basins, though this includes only 9 African basins, compared to 45 basins for North America and 36 basins for Europe for example, and hence the relationships developed from these datasets will be biased towards condi- 
tions observed in these regions and not necessarily reflective of African systems. Additionally, the NEWS2 model only takes into account contributions from sewage when areas are connected to sewage systems (i.e. point source inputs), which is not the case for 1.5 million residents of Nairobi, and may explain the major underestimation of the dissolved $\mathrm{PO}_{4}{ }^{3-}$ flux.

\subsection{Greenhouse gases}

The combination of high-frequency sampling and long-term monitoring of dissolved $\mathrm{CH}_{4}$ and $\mathrm{N}_{2} \mathrm{O}$ concentrations in the rivers of Africa remain scarce (Borges et al., 2015a). The average and median concentrations of $\mathrm{CH}_{4}$ in the Sabaki River $\left(483 \pm 530 \mathrm{nmolCH}_{4} \mathrm{~L}^{-1}\right.$ and $311 \mathrm{nmol} \mathrm{CH}_{4} \mathrm{~L}^{-1}$ respectively; $n=50$ ) often exceeded observations in other rivers of Africa, including the mid- and lower Tana River (54$387 \mathrm{nmol} \mathrm{CH}_{4} \mathrm{~L}^{-1}$; Bouillon et al., 2009), the Comoé, Bia and Tanoé rivers of Côte d'Ivoire $\left(48-870 \mathrm{nmol} \mathrm{CH}_{4} \mathrm{~L}^{-1}\right.$; Koné et al., 2010) and the Oubangui River of Central African Republic (74-280 nmol CH $\mathrm{L}_{4}^{-1}$; Bouillon et al., 2012). On a seasonal basis, $\mathrm{CH}_{4}$ concentrations tended to rise and fall with discharge (Fig. 7a), opposite to observations in the Oubangui and Côte d'Ivoire rivers where highest concentrations are observed during low-flow periods and decrease as discharge increases (Koné et al., 2010; Bouillon et al., 2012), and are likely linked to the increased supply of organic waste primed for decomposition from Nairobi. On the other hand, the highest peaks $\left(1857-2838 \mathrm{nmol} \mathrm{CH}_{4} \mathrm{~L}^{-1} ; 85171-\right.$ $135111 \%$ saturation) were observed over the dry JJAS dry seasons of 2012 and 2013, their timing coinciding with the peaks in POC, $\mathrm{PN}$ and $\mathrm{NH}_{4}{ }^{+}$previously discussed and attributed to large mammalian inputs, and we suggest these short-lived dry season $\mathrm{CH}_{4}$ peaks likely represent the decomposition of these mammalian-mediated terrestrial subsidies. $\mathrm{CH}_{4}$ showed two seasonal peaks, one during high water and another at the end of the low water period. The peak of $\mathrm{CH}_{4}$ during high water might be related to the increased connectivity between river and wetlands such as floodplains as reported in the Zambezi River (Teodoru et al., 2015), and in the Oubangui (Bouillon et al., 2012, 2014). The peak of $\mathrm{CH}_{4}$ at the end of the dry season is obviously unrelated to interaction with wetlands since at this period river and floodplains are hydrologically disconnected. We hypothesise that this increase of $\mathrm{CH}_{4}$ is related to the combination of increased water residence time and the additional inputs of organic matter from hippopotami. Indeed, they aggregate during low flow in river pools and river banks leading to a substantial input of organic matter (Subalusky et al., 2015) that we hypothesise leads to enhanced in-stream $\mathrm{CH}_{4}$ production. During high-water period, the hippopotami disperse across the landscape, presumably having a lower impact on river water biogeochemistry. Indeed, during the low water period $\mathrm{O}_{2}$ decreased in 2011, although the $\mathrm{CH}_{4}$ increase was modest. However, the marked increase of $\mathrm{CH}_{4}$ at the end of the 2013 dry season was mirrored by a distinct decrease of $\mathrm{O}_{2}$ saturation level from $\sim 100$ to $\sim 20 \%$. Although we provide no flux estimates, these elevated concentrations relative to observations in other African river systems at least hint that the A-G-S river system may be a relatively significant source of $\mathrm{CH}_{4}$ outgassing at the local scale.

Nitrous oxide in rivers is sourced from either nitrification or denitrification, and although the interest in $\mathrm{N}_{2} \mathrm{O}$ is growing due to its recognition as a significant contributor to radiative forcing (Hartmann et al., 2013) and as a major ozone depleting substance (Ravishankara et al., 2009), relatively limited datasets are available for rivers (see Baulch et al., 2011; Beaulieu et al., 2011; Marzadri et al., 2017) and very few for tropical systems specifically (see Guérin et al., 2008; Bouillon et al., 2012; Borges et al., 2015a). We observe similar seasonal patterns in the Sabaki River to those observed by Bouillon et al. (2012) in the Oubangui River, with concentrations during low-flow conditions typically hovering at $\sim 5-6 \mathrm{nmol} \mathrm{N}_{2} \mathrm{OL}^{-1}$ (Fig. 7b) and increasing as high-flow conditions approach, though our peak concentration $\left(26.6 \mathrm{nmol} \mathrm{N}_{2} \mathrm{OL}^{-1} ; 463 \%\right.$ saturation) is considerably higher than that reported for the largely pristine Oubangui River basin $\left(9.6 \mathrm{nmol} \mathrm{N}_{2} \mathrm{OL} \mathrm{L}^{-1} ; 165 \%\right.$ saturation), with this pattern reflecting well the concentrations observed at the monitoring station during the basin-wide campaigns of JJAS dry season $\left(6.3 \mathrm{nmol} \mathrm{N}_{2} \mathrm{OL}^{-1} ; 116 \%\right.$ saturation) and OND wet season $\left(15.8 \mathrm{nmol} \mathrm{N}_{2} \mathrm{OL} \mathrm{L}^{-1} ; 274 \%\right.$ saturation). The seasonal pattern reported from these African rivers is unique compared to temperate rivers, where the opposite pattern is more typical (Cole and Caraco, 2001b; Beaulieu et al., 2011). Given the reported correlation between $\mathrm{N}_{2} \mathrm{O}$ and $\mathrm{NO}_{3}{ }^{-}$concentrations in various river systems (Baulch et al., 2011; Beaulieu et al., 2011), including three from Africa (Borges et al., 2015a), and that basin-wide data shows gradually increasing concentrations from $\sim 179$ to $538 \mu \mathrm{mol} \mathrm{NO}_{3}{ }^{-} \mathrm{L}^{-1}$ over the $200 \mathrm{~km}$ reach directly upstream of the monitoring site during the OND wet season (see Marwick et al., 2014a), we make a first assumption that the elevated $\mathrm{N}_{2} \mathrm{O}$ concentrations during the wet season may be driven by upstream nitrification of the wastewater inputs identified in Marwick et al. (2014a).

\subsection{Future outlook}

The biogeochemical cycles and budgets of the Athi-GalanaSabaki river system have been considerably perturbed by the introduction of European agricultural practices in the early 20th century and the expanding population of Nairobi living with inadequate waste water facilities (Van Katwijk et al., 1993; Fleitmann et al., 2007). These factors have had considerable impact on riverine sediment loads (Fleitmann et al., 2007), instream nutrient cycling (Marwick et al., 2014a) and near-shore marine ecosystems in the vicinity of the Sabaki outlet (Giesen and van de Kerkhof, 1984; Van Katwijk et al., 1993). Recent modelling of nutrient export to the coastal 
zone of Africa to the year 2050 foreshadows continued perturbation to these ecosystems, with the extent dependant on the land management pathway followed and mitigation strategies in place (Yasin et al., 2010). Although suspended sediment fluxes are estimated to decrease over Africa in the coming 40 years, the projected increase in dissolved forms of $\mathrm{N}$ and $\mathrm{P}$ and decreases in particulate forms of $\mathrm{C}, \mathrm{N}$ and $\mathrm{P}$ as well as dissolved OC (Yasin et al., 2010) will further augment nutrient stoichiometry within the inland waters of the A-G-S system.

Although no large reservoirs have been developed within the A-G-S Basin, approval has been given for the construction of the Thwake Multipurpose Dam on the Athi River, though commencement has been delayed by tender approval for the project. The total surface area is expected to be in the vicinity of $29 \mathrm{~km}^{2}$, and the completed reservoir can be expected to have a considerable impact on the downstream geomorphology and biogeochemistry of the river, as experienced in the neighbouring reservoir-regulated Tana River (see Bouillon et al., 2009; Tamooh et al., 2012; Tamooh et al., 2014). Given lakes and reservoirs enhance the cycling and removal of nutrients due to their ability to prolong material residence times and subsequently enhance particle settling and in situ processing (Wetzel, 2001; Harrison et al., 2009), in addition to suggestions that GHG emissions from lentic systems of the tropics may be disproportionately large relative to temperate and northern latitude systems (Aufdenkampe et al., 2011; Bastviken et al., 2011; Borges et al., $2015 \mathrm{~b}$ ), it is reasonable to assume the planned reservoir on the Athi River will become a biogeochemical hotspot for the processing, storage and removal of upstream anthropogenicdriven nutrient loads. The datasets presented within Marwick et al. (2014a) and here provide critical base-line data for future research initiatives in the A-G-S system, not only to assess the evolving fluvial biogeochemistry of the basin in response to a newly constructed tropical reservoir but also, importantly, to review the influence damming has on nutrient and suspended sediment fluxes to the coastal zone, and subsequently the health and biodiversity of the Malindi-Watamu Marine National Park ecosystem.

Data availability. The full dataset can be found in the Supplement accompanying this article.

\section{The Supplement related to this article is available online at https://doi.org/10.5194/bg-15-1683-2018-supplement.}

Author contributions. TRM, lead author, conceived research, performed field sampling, performed sample and data analysis and wrote the paper. FT performed field sampling and sample analysis. BO performed field sampling. AVB conceived research, performed sample analysis and wrote the paper. FD performed sample analysis. SB conceived research, performed sample and data analysis and wrote the paper.

Competing interests. The authors declare that they have no conflict of interest.

Acknowledgements. Funding for this work was provided by the European Research Council (ERC-StG 240002, AFRIVAL, http://ees.kuleuven.be/project/afrival/), and by the Research Foundation Flanders (FWO-Vlaanderen, project G.0651.09). We thank Zita Kelemen (KU Leuven), Peter Salaets (KU Leuven) and MarcVincent Commarieu (ULg) for technical and laboratory assistance, and John Ngilu and W.R.M.A. (Water Resource Management Authority, Machakos, Kenya) for providing the discharge data. Thanks also to Christopher Still and Rebecca Powell for providing the GIS data layers of their isoscape models. Alberto Vieira Borges is a senior research associate at the FRS-FNRS (Belgium). We appreciate the constructive feedback from two anonymous referees and the handling editor, which helped to improve an earlier version of the manuscript.

Edited by: Gwenaël Abril

Reviewed by: two anonymous referees

\section{References}

Abrantes, K. G., Barnett, A., Marwick, T. R., and Bouillon, S.: Importance of terrestrial subsidies for estuarine food webs in contrasting East African catchments, Ecosphere, 4, Article 14, https://doi.org/10.1890/ES12-00322.1, 2013.

Abril, G., Commarieu, M. V., and Guérin, F.: Enhanced methane oxidation in an estuarine turbidity maximum, Limnol. Oceanogr., 52, 470-475, 2007.

Abril, G., Martinez, J.-M., Artigas, L. F., Moreira-Turcq, P., Benedetti, M. F., Vidal, L., Meziane, T., Kim, J.-H., Bernardes, M. C., Savoye, N., Deborde, J., Albéric, P., Souza, M. F. L., Souza, E. L., and Roland, F.: Amazon River carbon dioxide outgassing fuelled by wetlands, Nature, 505, 395-398, 2014.

Aitkenhead, J. A. and McDowell, W. H.: Soil C: N ratio as a predictor of annual riverine DOC flux at local and global scales, Global Biogeochem. Cy., 14, 127-138, https://doi.org/10.1029/1999GB900083, 2000.

Aravena, R., Evans, M. L., and Cherry, J. A.: Stable isotopes of oxygen and nitrogen in source identification of nitrate from septic systems, Ground Water, 31, 180-186, https://doi.org/10.1111/j.1745-6584.1993.tb01809.x, 1993.

Aufdenkampe, A. K., Mayorga, E., Raymond, P. A., Melack, J. M., Doney, S. C., Alin, S. R., Aalto, R. E., and Yoo, K.: Riverine coupling of biogeochemical cycles between land, oceans, and atmosphere, Front. Ecol. Environ., 9, 53-60, https://doi.org/10.1890/100014, 2011.

Bastviken, D., Tranvik, L. J., Downing, J. A., Crill, P. M., and Enrich-Prast, A.: Freshwater methane emissions offset the continental carbon sink, Science, 331, p. 50, https://doi.org/10.1126/science.1196808, 2011. 
Battin, T. J., Kaplan, L. A., Findlay, S., Hopkinson, C. S., Marti, E., Packman, A. I., Newbold, J. D., and Sabater, F.: Biophysical controls on organic carbon fluxes in fluvial networks, Nat. Geosci., 1, 95-100, https://doi.org/10.1038/ngeo101, 2008.

Battin, T. J., Luyssaert, S., Kaplan, L. A., Aufdenkampe, A. K., Richter, A., and Tranvik, L. J.: The boundless carbon cycle, Nat. Geosci., 2, 598-600, https://doi.org/10.1038/ngeo618, 2009.

Baulch, H. M., Schiff, S. L., Maranger, R., and Dillon, P. J.: Nitrogen enrichment and the emission of nitrous oxide from streams, Global Biogeochem. Cy., 25, GB4013, https://doi.org/10.1029/2011GB004047, 2011.

Beaulieu, J. J., Tank, J. L., Hamilton, S. K., Wollheim, W. M., Hall Jr., R. O., Mulholland, P. J., Peterson, B. J., Ashkenas, L. R., Cooper, L. W., Dahm, C. N., Dodds, W. K., Grimm, N. B., Johnson, S. L., McDowell, W. H., Poole, G. C., Valett, H. M., Arango, C. P., Bernot, M. J., Burgin, A. J., Crenshaw, C. L., Helton, A. M., Johnson, L. T., O’Brien, J. M., Potter, J. D., Sheibley, R. W., Sobota, D. J., and Thomas, S. M.: Nitrous oxide emission from denitrification in stream and river networks, P. Natl. Acad. Sci. USA, 108, 214-219, https://doi.org/10.1073/pnas.1011464108, 2011.

Beusen, A. H. W., Dekkers, A. L. M., Bouwman, A. F., Ludwig, L., and Harrison, J.: Estimation of global river transport of sediments and associated particulate C, N, and P, Global Biogeochem. Cy., 19, GB4S05, https://doi.org/10.1029/2005GB002453, 2005.

Bird, M. I. and Pousai, P.: Variations of $\delta 13 \mathrm{C}$ in the surface soil organic carbon pool, Global Biogeochem. Cy., 11, 313-322, https://doi.org/10.1029/97GB01197, 1997.

Bird, M. I., Fyfe, W. S., Pinheiro-Dick, D., and Chivas, A. R.: Carbon isotope indicators of catchment vegetation in the Brazilian Amazon, Global Biogeochem. Cy., 6, 293-306, https://doi.org/10.1029/92GB01652, 1992.

Bird, M. I., Giresse, P., and Chivas, A. R.: Effect of forest and savanna vegetation on the carbon-isotope composition from the Sanaga River, Cameroon, Limnol. Oceanogr., 39, 1845-1854, https://doi.org/10.4319/lo.1994.39.8.1845, 1994.

Bird, M. I., Giresse, P., and Ngos, S.: A seasonal cycle in the carbon-isotope composition of organic carbon in the Sanaga River, Cameroon, Limnol. Oceanogr., 43, 143-146, https://doi.org/10.4319/lo.1998.43.1.0143, 1998.

Borges, A. V., Darchambeau, F., Teodoru, C. R., Marwick, T. R., Tamooh, F., Geeraert, N., Omengo, F., Guérin, F., Lambert, T., Morana, C., Okuku, E., and Bouillon, S.: Globally significant greenhouse-gas emissions from African inland waters, Nat. Geosci., 8, 637-642, https://doi.org/10.1038/ngeo2486, 2015a.

Borges, A. V., Abril, G., Darchambeau, F., Teodoru, C. R., Deborde, J., Vidal, L. O., Lambert, T., and Bouillon, S.: Divergent biophysical controls of aquatic $\mathrm{CO}_{2}$ and $\mathrm{CH}_{4}$ in the World's two largest rivers, Scientific Reports, 5, 15614, https://doi.org/10.1038/srep15614, 2015b.

Bouillon, S., Korntheuer, M., Baeyens, W., and Dehairs, F.: A new automated setup for stable isotope analysis of dissolved organic carbon, Limnol. Oceanogr.-Meth., 4, 216-226, 2006.

Bouillon, S., Abril, G., Borges, A. V., Dehairs, F., Govers, G., Hughes, H. J., Merckx, R., Meysman, F. J. R., Nyunja, J., Osburn, C., and Middelburg, J. J.: Distribution, origin and cycling of carbon in the Tana River (Kenya): a dry season basin-scale survey from headwaters to the delta, Biogeosciences, 6, 2475-2493, https://doi.org/10.5194/bg-6-2475-2009, 2009.
Bouillon, S., Yambélé, A., Spencer, R. G. M., Gillikin, D. P., Hernes, P. J., Six, J., Merckx, R., and Borges, A. V.: Organic matter sources, fluxes and greenhouse gas exchange in the Oubangui River (Congo River basin), Biogeosciences, 9, 2045-2062, https://doi.org/10.5194/bg-9-2045-2012, 2012.

Bouillon, S., Yambélé, A., Gillikin, D. P., Teodoru, C., Darchambeau, F., Lambert, T., and Borges, A. V.: Contrasting biogeochemical characteristics of the Oubangui River and tributaries (Congo River Basin), Scientific Reports, 4, 5402, https://doi.org/10.1038/srep05402, 2014.

Buontempo, C., Mathison, C., Jones, R., Williams, K., Wang, C., and McSweeney, C.: An ensemble climate projection for Africa, Clim. Dynam., 44, 2097-2118, https://doi.org/10.1007/s00382014-2286-2, 2015.

Champion, A. M.: Soil erosion in Africa, Geogr. J., 82, 130-139, https://doi.org/10.2307/1785660, 1933.

Ciais, P., Bombelli, A., Williams, M., Piao, S. L., Chave, J., Ryan, C. M., Henry, M., Brender, P., and Valentini, R.: The carbon balance of Africa: synthesis of recent research studies, Philos. T. Roy. Soc. A, 369, 2038-2057, https://doi.org/10.1098/rsta.2010.0328, 2011.

Ciais, P., Sabine, C., Bala, G., Bopp, L., Brovkin, V., Canadell, J., Chhabra, A., DeFries, R., Galloway, J., Heimann, M., Jones, C., Le Quéré, C., Myneni, R. B., Piao, S., and Thornton, P.: Carbon and Other Biogeochemical Cycles, Climate Change 2013: The Physical Science Basis. Contribution of Working Group I to the Fifth Assessment Report of the Intergovernmental Panel on Climate Change, edited by: Stocker, T. F., Qin, D., Plattner, G.-K., Tignor, M., Allen, S. K., Boschung, J., Nauels, A., Xia, Y., Bex, V. and Midgley, P. M., Cambridge University Press, Cambridge, UK and New York, NY, USA, 465-570, https://doi.org/10.1017/CBO9781107415324.015, 2013.

Cole, J. J. and Caraco, N. F.: Carbon in catchments: connecting terrestrial carbon losses with aquatic metabolism, Mar. Freshwater Res., 52, 101-110, https://doi.org/10.1071/MF00084, 2001a.

Cole, J. J. and Caraco, N. F.: Emissions of nitrous oxide $\left(\mathrm{N}_{2} \mathrm{O}\right)$ from a tidal, freshwater river, the Hudson River, New York, Environ. Sci. Technol., 35, 991-996, 2001b.

Cole, J. J., Prairie, Y. T., Caraco, N. F., McDowell, W. H., Tranvik, L. J., Striegl, R. G., Duarte, C. M., Kortelainen, P., Downing, J. A., Middelburg, J. J., and Melack, J.: Plumbing the global carbon cycle: Integrating inland waters into the terrestrial carbon budget, Ecosystems, 10, 171-184, https://doi.org/10.1007/s10021006-9013-8, 2007.

Coynel, A., Seyler, P., Etcheber, H., Meybeck, M., and Orange, D.: Spatial and seasonal dynamics of total suspended sediment and organic carbon species in the Congo River, Global Biogeochem. Cy., 19, GB4019, https://doi.org/10.1029/2004GB002335, 2005.

Dafe, F.: No business like slum business? The political economy of the continued existence of slums: a case study of Nairobi, DESTIN: Development Studies Institute, Working Paper Series, No. 09-98, 2009.

Delft Hydraulics: Malindi Bay Pollution II, Field measurements and recommendations, Report R611, Delft Hydraulics Laboratory, Delft, the Netherlands, 1970.

Dosio, A. and Panitz, H. J.: Climate change projections for CORDEX-Africa with COSMO-CLM regional climate model and differences with the driving global climate models, Clim. 
Dynam., 46, 1599-1625, https://doi.org/10.1007/s00382-0152664-4, 2016.

Drake, T. W., Raymond, P. A., and Spencer, R. G. M.: Terrestrial carbon inputs to inland waters: A current synthesis of estimates and uncertainty, Limnol. Oceanogr. Lett., https://doi.org/10.1002/lol2.10055, in press, 2018.

Dunne, T.: Sediment yield and land use in tropical catchments, J. Hydrol., 42, 281-300, https://doi.org/10.1016/00221694(79)90052-0, 1979.

Finn, D.: Land use and abuse in the East African region, Ambio, 12, 296-301, 1983.

Fleitmann, D., Dunbar, R. B., McCulloch, M., Mudelsee, M., Vuille, M., McClanahan, T. R., Cole, J. E., and Eggins, S.: East African soil erosion recorded in a 300 year old coral colony from Kenya, Geophys. Res. Lett., 34, L04401, https://doi.org/10.1029/2006GL028525, 2007.

Geeraert, N., Omengo, F. O., Tamooh, F., Marwick, T. R., Borges, A. V., Govers, G., and Bouillon, S.: Seasonal and inter-annual variations in carbon fluxes in a tropical river system (Tana River, Kenya), Aquat. Sci., 80, https://doi.org/10.1007/s00027018-0573-4, 2018.

Giesen, W. and Van de Kerkhof, K.: The impact of river discharges on the Kenya coral reef ecosystem - the physical processes, Part II: Effect on the Malindi-Watamu coastal environment, Report no. 194, Laboratory of Aquatic Ecology, Catholic University, Nijmegen, the Netherlands, 1984

Gillikin, D. P. and Bouillon, S.: Determination of $\delta^{18} \mathrm{O}$ of water and $\delta^{13} \mathrm{C}$ of dissolved inorganic carbon using a simple modification of an elemental analyser-isotope ratio mass spectrometer: an evaluation, Rapid Commun. Mass Sp., 21, 1475-1478, https://doi.org/10.1002/rcm.2968, 2007.

GOK-TARDA: Athi River Basin: Pre-investment Study: Preliminary Report, Agrar-UND Hydrotechnik Gmbh, Essen, Watermeyer, Legge, Piesold \& Uhlmann, London Consulting Engineers, London, UK, 1981.

Grey, J. and Harper, D. M.: Using stable isotope analyses to identify allochthonous inputs to Lake Naivasha mediated via the hippopotamus gut, Isot. Environ. Healt. S., 38, 245-250, 2002.

Guérin, F., Abril, G., Tremblay, A., and Delmas, R.: Nitrous oxide emissions from tropical hydroelectric reservoirs, Geophys. Res. Lett., 35, L06404, https://doi.org/10.1029/2007GL033057, 2008.

Hamilton, S. K.: Biogeochemical implications of climate change for tropical rivers and floodplains, Hydrobiologia, 657, 19-35, https://doi.org/10.1007/s10750-009-0086-1, 2010.

Hamilton, S. K., Sippel, S., Calheiros, D. F., and Melack, J. F.: An anoxic event and other biogeochemical effects of the Pantanal wetland on the Paraguay river, Limnol. Oceanogr., 4, 257-272, 1997.

Harrison, J. A., Maranger, R. J., Alexander, R. B., Giblin, A. E., Jacinthe, P. A., Mayorga, E., Seitzinger, S. P., Sobota, D. J., and Wollheim, W. M.: The regional and global significance of nitrogen removal in lakes and reservoirs, Biogeochemistry, 93, 143157, https://doi.org/10.1007/s10533-008-9272-x, 2009.

Hartmann, D. L., Klein Tank, A. M. G., Rusticucci, M., Alexander, L. V., Brönnimann, S., Charabi, Y., Dentener, F. J., Dlugokencky, E. J., Easterling, D. R., Kaplan, A., Soden, B. J., Thorne, P. W., Wild, M., and Zhai, P. M.: Observations: Atmosphere and Surface, Climate Change 2013: The Physical Science Basis, Contribution of Working Group I to the Fifth Assessment Report of the Intergovernmental Panel on Climate Change, edited by: Stocker, T. F., Qin, D., Plattner, G.-K., Tignor, M., Allen, S. K., Boschung, J., Nauels, A., Xia, Y., Bex V., and Midgley, P. M., Cambridge University Press, Cambridge, UK and New York, NY, USA, 2013.

IPCC: Climate Change 2013: The Physical Science Basis. Contribution of Working Group I to the Fifth Assessment Report of the Intergovernmental Panel on Climate Change, edited by: Stocker, T. F., Qin, D., Plattner, G.-K., Tignor, M., Allen, S. K., Boschung, J., Nauels, A., Xia, Y., Bex, V., and Midgley, P.M., Cambridge University Press, Cambridge, UK and New York, NY, USA 1535 pp., https://doi.org/10.1017/CBO9781107415324, 2013.

Ittekkot, V. and Zhang, S.: Pattern of particulate nitrogen transport in world rivers, Global Biogeochem. Cy., 3, 383-391, https://doi.org/10.1029/GB003i004p00383, 1989.

Kitheka, J. U.: River sediment supply, sedimentation and transport of the highly turbid sediment plume in Malindi Bay, Kenya, J. Geogr. Sci., 23, 465-489, https://doi.org/10.1007/s11442-0131022-x, 2013.

Kitheka, J. U., Obiero, M., and Nthenge, P.: River discharge, sediment transport and exchange in the Tana estuary, Kenya, Estuar. Coast. Shelf S., 63, 455-468, https://doi.org/10.1016/j.ecss.2004.11.011, 2005.

Kithiia, S. M.: Land use changes and their effects on sediment transport and soil erosion within the Athi drainage basin, Kenya, IAHS-AISH P., 245, 145-150, 1997.

Kithiia, S. M. and Wambua, B. N.: Temporal changes of sediment dynamics within the Nairobi River sub-basins between 1998-2006 time scale, Kenya, Annals of Warsaw University of Life Sciences - SGGW, Land Reclamation, 42, 17-22 https://doi.org/10.2478/v10060-008-0060-z, 2010.

Koné, Y. J. M., Abril, G., Delille, B., and Borges, A. V.: Seasonal variability of methane in the rivers and lagoons of Ivory Coast (West Africa), Biogeochemistry, 100, 21-37, https://doi.org/10.1007/s10533-009-9402-0, 2010.

Lehner, B., Verdin, K., and Jarvis, A.: HydroSHEDS Technical Documentation, World Wildlife Fund US, Washington, DC, USA, http://hydrosheds.cr.usgs.gov (last access: 15 January 2018), 2006.

Lesack, L. F. W., Hecky, R. E., and Melack, J. M.: Transport of carbon, nitrogen, phosphorous and major solutes in the Gambia River, West Africa, Limnol. Oceanogr, 29, 816-830, https://doi.org/10.4319/lo.1984.29.4.0816, 1984.

Ludwig, W., Probst, J. L., and Kempe, S.: Predicting the oceanic input of organic carbon by continental erosion, Global Biogeochem. Cy., 10, 23-41, https://doi.org/10.1029/95GB02925, 1996.

Mariotti, A., Gadel, F., and Giresse, P.: Carbon isotope composition and geochemistry of particulate organic matter in the Congo River (Central Africa): application to the study of Quaternary sediments off the mouth of the river, Chem. Geol., 86, 345-357, https://doi.org/10.1016/0168-9622(91)90016-P, 1991.

Marwick, T. R., Tamooh, F., Ogwoka, B., Teodoru, C., Borges, A. V., Darchambeau, F., and Bouillon, S.: Dynamic seasonal nitrogen cycling in response to anthropogenic $\mathrm{N}$ loading in a tropical catchment, Athi-Galana-Sabaki River, Kenya, Biogeosciences, 11, 443-460, https://doi.org/10.5194/bg-11-443-2014, 2014a.

Marwick, T. R., Borges, A. V., Van Acker, K., Darchambeau, F., and Bouillon, S.: Disproportionate Contribution of Riparian Inputs to 
Organic Carbon Pools in Freshwater Systems, Ecosystems, 17, 974-989, https://doi.org/10.1007/s10021-014-9772-6, 2014b.

Marzadri, A., Dee, M. M., Tonina, D., Bellin, A., and Tank, J. L.: Role of surface and subsurface processes in scaling $\mathrm{N}_{2} \mathrm{O}$ emissions along riverine networks, P. Natl. Acad. Sci. USA, 114, 4330-4335, 10.1073/pnas.1617454114, 2017.

Masese, F. O., Abrantes, K. G., Gettel, G. M., Bouillon, S., Irvine, K., and McClain, M. E.: Are large herbivores vectors of terrestrial subsidies for riverine food webs?, Ecosystems, 18, 686-706, https://doi.org/10.1007/s10021-015-9859-8, 2015.

Mayaux, P., Bartholomé, E., Fritz, S., and Belward, A.: A new landcover map of Africa for the year 2000, J. Biogeogr., 31, 861-877. https://doi.org/10.1111/j.1365-2699.2004.01073.x, 2004.

Mayorga, E., Seitzinger, S. P., Harrison, J. A., Dumont, E., Beusen, A. H. W., Bouwman, A. F., Fekete, B. M., Kroeze, C., and Van Drecht, A.: Global nutrient export from WaterSheds 2 (NEWS 2): model development and implementation, Environ. Modell. Softw., 25, 837-853, https://doi.org/10.1016/j.envsoft.2010.01.007, 2010.

Meehl, G. A., Stocker, T. F., Collins, W. D., Friedlingstein, P., Gaye, A. T., Gregory, J. M., Kitoh, A., Knutti, R., Murphy, J. M., Noda, A., Raper, S. C. B., Watterson, I. G., Weaver, A. J., and Zhao, Z.-C.: Global climate projections, in: Climate Change 2007: The Physical Science Basis. Contribution of Working Group I to the Fourth Assessment Report of the Intergovernmental Panel on Climate Change, edited by: Solomon, S., Qin, D., Manning, M., Chen, Z., Marquis, M., Averyt, K. B., Tignor, M., and Miller, H. L., Cambridge University Press, Cambridge, UK, 2007.

Meybeck, M.: Carbon, nitrogen, and phosphorus transport by world rivers, Am. J. Sci. 282, 401-450, https://doi.org/10.2475/ajs.282.4.401, 1982.

Milliman, J. D. and Farnsworth, K. L.: River discharge to the coastal ocean: a global synthesis, Cambridge University Press, New York, USA, 2011.

Moore, S., Gauci, V., Evans, C. D., and Page, S. E.: Fluvial organic carbon losses from a Bornean blackwater river, Biogeosciences, 8, 901-909, https://doi.org/10.5194/bg-8-901-2011, 2011.

Mogaka, H., Gichere, S., Davis, R., and Hirji, R.: Climate variability and water resources degradation in Kenya: improving water resources development and management, World Bank Working Papers, 69, World Bank, Washington D.C., USA, 2006.

Munyao, T. M., Tole, M. P., and Jungerius, P. D.: Sabaki River sediment transport and deposition in the Indian Ocean, Research reports - African Studies Centre Leiden, Leiden, the Netherlands, 2003.

Ngene, S., Ihwagi, F., Nzisa, M., Mukeka, J., Njumbi, S., and Omondi, P.: Total aerial census of elephants and other large mammals in the Tsavo-Mkomazi ecosystem, Kenya Wildlife Service report, 2011.

Oeurng, C., Sauvage, S., Coynel, A., Maneux, E., Etcheber, H., and Sanchez-Perez, M. J.: Fluvial transport of suspended sediment and organic carbon during flood events in a large agricultural catchment in southwest France, Hydrol. Process., 25, 23652378, https://doi.org/10.1002/hyp.7999, 2011.

Ravishankara, A. R., Daniel, J. S., and Portmann, R. W.: Nitrous oxide $\left(\mathrm{N}_{2} \mathrm{O}\right)$ : the dominant ozone-depleting substance emitted in the 21st century, Science, 326, 123-125, https://doi.org/10.1126/science.1176985, 2009.
Raymond, P. A., Hartmann, J., Lauerwald, R., Sobek, S., McDonald, C., Hoover, M., Butman, D., Striegl, R., Mayorga, E., Humborg, C., Kortelainen, P., Dürr, H., Meybeck, M., Ciais, P., and Guth, P.: Global carbon dioxide emissions from inland waters, Nature, 503, 355-359, https://doi.org/10.1038/nature12760, 2013.

Regnier, P., Friedlingstein, P., Ciais, P., Mackenzie, F. T., Gruber, N., Janssens, I. A., Laruelle, G. G., Lauerwald, R., Luyssaert, S., Andersson, A. J., Arndt, S., Arnosti, C., Borges, A. V., Dale, A. W., Gallego-Sala, A., Goddéris, Y., Goossens, N., Hartmann, J., Heinze, C., Ilyina, T., Joos, F., LaRowe, D. E., Leifeld, J., Meysman, F. J. R., Munhoven, G., Raymond, P. A., Spahni, R., Suntharalingam, P., and Thullner, M.: Anthropogenic perturbation of the carbon fluxes from land to ocean, Nat. Geosci., 6, 597-607, https://doi.org/10.1038/ngeo1830, 2013.

Rovira, A. and Batalla, R.: Temporal distribution of suspended sediment transport in a Mediterranean basin: The Lower Tordera (NE Spain), Geomorphology, 79, 58-71, https://doi.org/10.1016/j.geomorph.2005.09.016, 2006.

Schlünz, B. and Schneider, R. R.: Transport of terrestrial organic carbon to the oceans by rivers: re-estimating flux and burial rates, Int. J. Earth Sci., 88, 599-606, https://doi.org/10.1007/s005310050290, 2000.

Spitzy, A. and Leenheer, J.: Dissolved organic carbon in rivers, in: Biogeochemistry of Major World Rivers, edited by: Degens,E. T., Kempe, S., and Richey, J. E., John Wiley and Sons, Chichester, UK, 213-232, 1991.

Stanley, E. H., Casson, N. J., Christel, S. T., Crawford, J. T., Loken, L. C., and Oliver, S. K.: The ecology of methane in streams and rivers: patterns, controls, and global significance, Ecol. Monogr., 86, 146-171, https://doi.org/10.1890/15-1027, 2016.

Still, C. J. and Powell, R. L.: Continental-scale distributions of vegetation stable carbon isotope ratios, in Isoscapes, edited by: West, J. B., Bowen, G. J., Dawson, T. E., and Tu, K. P., 179-193, Springer, the Netherlands, 2010.

Subalusky, A. L., Dutton, C. L., Rosi-Marshall, E. J., and Post, D. M.: The hippopotamus conveyor belt: vectors of carbon and nutrients from terrestrial grasslands to aquatic systems in subSaharan Africa, Freshwater Biol., 60, 512-525, 2015.

Syvitski, J. P., Vörösmarty, C. J., Kettner, A. J., and Green, P.: Impact of humans on the flux of terrestrial sediment to the global coastal ocean, Science, 308(, 376-380, 2005.

Tamooh, F., Van den Meersche, K., Meysman, F., Marwick, T. R., Borges, A. V., Merckx, R., Dehairs, F., Schmidt, S., Nyunja, J., and Bouillon, S.: Distribution and origin of suspended sediments and organic carbon pools in the Tana River Basin, Kenya, Biogeosciences, 9, 2905-2920, https://doi.org/10.5194/bg-9-29052012, 2012.

Tamooh, F., Meysman, F. J., Borges, A. V., Marwick, T. R., Van Den Meersche, K., Dehairs, F., and Bouillon, S.: Sediment and carbon fluxes along a longitudinal gradient in the lower Tana River (Kenya), J. Geophys. Res.-Biogeo., 119, 1340-1353, https://doi.org/10.1002/2013JG002358, 2014.

Teodoru, C. R., Nyoni, F. C., Borges, A. V., Darchambeau, F., Nyambe, I., and Bouillon, S.: Dynamics of greenhouse gases $\left(\mathrm{CO}_{2}, \mathrm{CH} 4, \mathrm{~N}_{2} \mathrm{O}\right)$ along the Zambezi River and major tributaries, and their importance in the riverine carbon budget, Biogeosciences, 12, 2431-2453, https://doi.org/10.5194/bg-122431-2015, 2015. 
Tranvik, L. J., Downing, J. A., Cotner, J. B., Loiselle, S. A., Striegl, R. G., Ballatore, T. J., Dillon, P., Finlay, K., Fortino, K., Knoll, L. B., Kortelainen, P. L., Kutser, T., Larsen, S., Laurion, I., Leech, D. M., McCallister, S. L., McKnight, D. M., Melack, J. M., Overholt, E., Porter, J. A., Prairie, Y., Renwick, W. H., Roland, F., Sherman, B. S., Schindler, D. W., Sobek, S., Tremblay, A., Vanni, M. J., Verschoor, A. M., von Wachenfeldt, E., and Weyhenmeyer, G. A.: Lakes and reservoirs as regulators of carbon cycling and climate, Limnol. Oceanogr., 54, 2298-2314, https://doi.org/10.4319/lo.2009.54.6_part_2.2298, 2009.

United Nations: Department of Economic and Social Affairs, Population Division: World Population Prospects: The 2012 Revision, Volume I: Comprehensive Tables ST/ESA/SER.A/336, 2013.

Valentini, R., Arneth, A., Bombelli, A., Castaldi, S., Cazzolla Gatti, R., Chevallier, F., Ciais, P., Grieco, E., Hartmann, J., Henry, M., Houghton, R. A., Jung, M., Kutsch, W. L., Malhi, Y., Mayorga, E., Merbold, L., Murray-Tortarolo, G., Papale, D., Peylin, P., Poulter, B., Raymond, P. A., Santini, M., Sitch, S., Vaglio Laurin, G., van der Werf, G. R., Williams, C. A., and Scholes, R. J.: A full greenhouse gases budget of Africa: synthesis, uncertainties, and vulnerabilities, Biogeosciences, 11, 381-407, https://doi.org/10.5194/bg-11-381-2014, 2014.2014.

Van Katwijk, M., Meier, N. F., Loon, R. V., Hove, E. V., Giesen, W. B. J. T., Velde, G. V. D., and Hartog, C. D.: Sabaki river sediment load and coral stress: correlation between sediments and condition of the Malindi-Watamu reefs in Kenya (Indian Ocean), Mar. Biol., 117, 675-683, https://doi.org/10.1007/BF00349780, 1993.
Vanmaercke, M., Poesen, J., Broeckx, J., and Nyssen, J.: Sediment yield in Africa, Earth-Sci. Rev., 136, 350-368, https://doi.org/10.1016/j.earscirev.2014.06.004,

Weiss, R. F.: Determinations of carbon dioxide and methane by dual catalyst flame ionization chromatography and nitrous oxide by electron capture chromatography, J. Chromatogr. Sci., 19, 611616, https://doi.org/10.1093/chromsci/19.12.611, 1981.

Weiss, R. F. and Price, B. A.: Nitrous oxide solubility in water and seawater, Mar. Chem., 8, 347-359, https://doi.org/10.1016/03044203(80)90024-9, 1980.

Wetzel, R. G.: Limnology, 3rd edn., Lake and river ecosystems, Academic Press, San Diego, CA, USA, 2001.

Widory, D., Petelet-Giraud, E., Negrel, P., and Ladouche, B.: Tracking the sources of nitrate in groundwater using coupled nitrogen and boron isotopes: a synthesis, Environ. Sci. Technol., 39, 539548, https://doi.org/10.1021/es0493897, 2005.

Yamamoto, S., Alcauskas, J. B., and Crozier, T. E.: Solubility of methane in distilled water and seawater, J. Chem. Eng. Data, 21, 78-80, https://doi.org/10.1021/je60068a029, 1976.

Yasin, J. A., Kroeze, C., and Mayorga, E.: Nutrients export by rivers to the coastal waters of Africa: past and future trends, Global Biogeochem. Cy., 24, GB0A07, https://doi.org/10.1029/2009GB003568, 2010.

Zurbrügg, R., Suter, S., Lehmann, M. F., Wehrli, B., and Senn, D. B.: Organic carbon and nitrogen export from a tropical dam-impacted floodplain system, Biogeosciences, 10, 23-38, https://doi.org/10.5194/bg-10-23-2013, 2013. 